Louisiana State University

LSU Digital Commons

1962

\title{
Organizational Conditions and Behavior in 234 Industrial Manufacturing Organizations.
}

George Henry Dunteman

Louisiana State University and Agricultural \& Mechanical College

Follow this and additional works at: https://digitalcommons.Isu.edu/gradschool_disstheses

\section{Recommended Citation}

Dunteman, George Henry, "Organizational Conditions and Behavior in 234 Industrial Manufacturing Organizations." (1962). LSU Historical Dissertations and Theses. 776.

https://digitalcommons.Isu.edu/gradschool_disstheses/776

This Dissertation is brought to you for free and open access by the Graduate School at LSU Digital Commons. It has been accepted for inclusion in LSU Historical Dissertations and Theses by an authorized administrator of LSU Digital Commons. For more information, please contact gradetd@lsu.edu. 
This dissertation has been $63-2770$ microfilmed exactly as received

DUNTEMAN, George Henry, 1935-

ORGANIZATIONAL CONDITIONS AND BEHAVIOR IN 234 INDUSTRIAL MANUFACTURING ORGANIZATIONS.

Louisiana State University, Ph.D., 1962

Psychology, general

University Microfilms, Inc., Ann Arbor, Michigan 
ORGANIZATIONAL CONDITIONS AND BEHAVIOR

IN 234

INDUSTRIAI MANUFACTURING ORGANIZATIONS

A Dissertation

Submitted to the Graduate Faculty of the Louisiana State University and Agricultural and Mechanical College

in partial fulfillment of the requirements for the degree of Doctor of Philosophy

in

The Department of Psychology

by

George Henry Dunteman

B.A., Saint Lawrence University, 1957

M.S., Iowa State University, 1959

August, 1962 


\section{ACKNOWLEDGMENTS}

The writer wishes to express his sincere appreciation to Dr. George J. Palmer, Jr. for the time, advice, and enthusiasm that he contributed throughout this investigation. Thanks are also due to Dr. Robert N. Vidulich, Dr. Roland L. Frye, Dr. Joel R. Butler, and Mr. Lawrence Mann for their helpful advice and criticisms.

I would also like to express my appreciation to Dr. Bill Townsend, Mr. Lew Harkins, and Mr. Orion Campbell of the Louisiana State University Computer Center for their cooperation in data processing.

The statistical and technical advice of Dr. Paul Baker of the Baton Rouge Humble Refinery was very much appreciated. The writer expresses his thanks to Mrs. Vera M. Foil for the typing of the completed manuscript.

I would also like to express my thanks to Mr. George Forman for his diligent efforts in a number of arduous clerical tasks.

This study was supported in part by Contract Nonr 1575(05), Project NR 170-478, between the Group Psychology Branch, Office of Naval Research, and Louisiana State University. 
PAGE

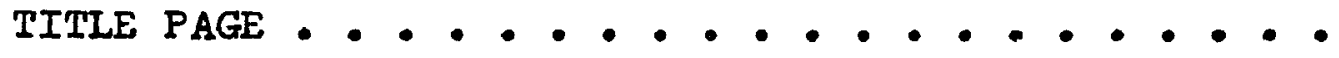

ACKMOWLEDGMNTS . . . . . . . . . . . . . . 11

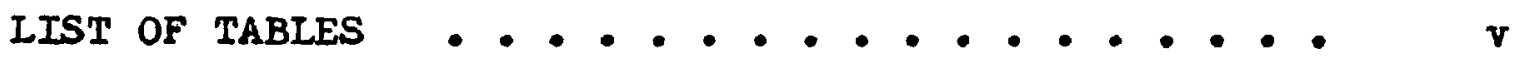

ABSTRACT $\bullet . \cdot \cdot \cdot \cdot \cdot \cdot \cdot \cdot \cdot \cdot \cdot \cdot \cdot \cdot \cdot \cdot \cdot \cdot \cdot \quad$ v1

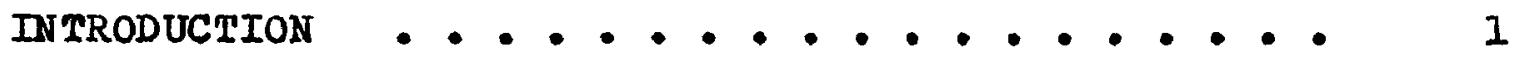

Approaches to Organization Theory . . . . . 1

Iaboratory Studies . . . . . . . . . . . 2

Field Experiments . . . . . . . . . . . 3

Intraorganizational Studies . . . . . . . . 3

Organizational Sampling Surveys . . . . . . 5

The Present Study . . . . . . . . . . . 6

PROCEDURE . . . . . . . . . . . . . . . 14

Questionnaire .. . . . . . . . . . . 14

Sample Survey . . . . . . . . . . . . 14

Reliability of Reports . . . . . . . . . 14

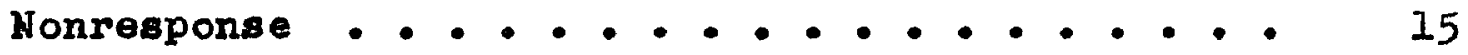

Data Analysis . . . . . . . . . . . 15

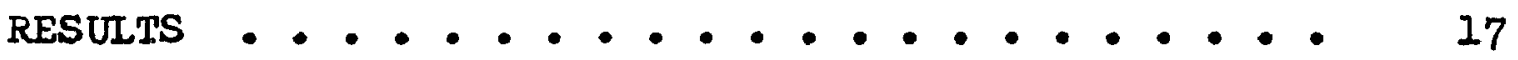

Returns . . . . . . . . . . . . . . 17

Reliability of Reports . . . . . . . . . 17

Nonresponse B1as . . - . . . - . . . . 25

Factors . . . . . . . . . . . . . 25 
TABLE OF CONTENTS Cont $d$.

PAGE

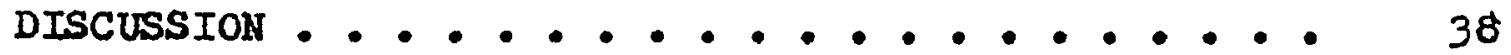

Company and Formal Organization Characterist1os - $\quad 38$

Management Attributes ............. 40

Incentive Conditions, Benefits, and Programs . . 41

Worker Characteristics . . . . . . . . 43

Personnel Performance . . . . . . . . . 45 .

Organizational Functioning . . . . . . . . 46

The Complexity of Organizational Attributes and

Beharior . . . . . . . . . . . . . . 47

SUMMARI AND CONCLUSIONS . . . . . . . . . . . 49

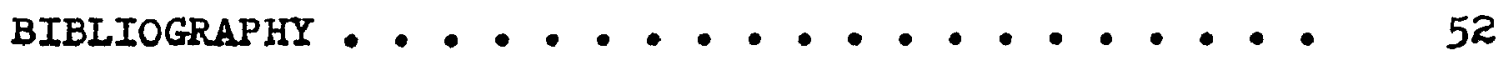

APPENDIX

A Item D1stributions . . . . . . . . 56

B Organization Questionnaire . . . . . . . 66

C IBM Mark Sense Cards . . . . . . . . 70

D Covering Letter for Initial Survey . . . . . 74

E Covering Letter for Reliability Sample . . . 76

F Covering Letter for Follow up Sample . . . . 78

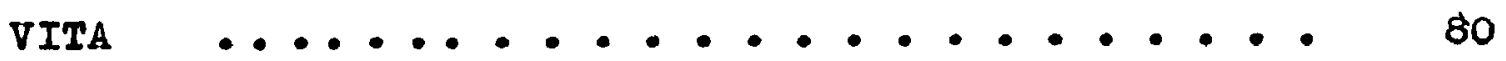




\section{IIST OF TABLES}

TABLE

PAGE

I Returns by Product Classification $(\mathrm{N}=234) \cdot \cdots 18$

II Returns by Geographic Location (N-234) • • 19

III Reliabilities for Original Respondents and Proportions for Original and Nonrespondent Returns .... .......... 20

IV Factor Structure of Organizational Attributes and Behavior . . . . . . . . . . 27 
ABSTRACT

The purpose of this study was to explore some of the interrelationships among 84 variables pertaining to company and formal organization characteristics, management attributes, incentive conditions, worker characteristics, personnel performance, and organizational functions in a sample of manufacturing firms. The correlations among the 84 variables were factor analyzed and the factors rotated to a simple structure.

Fourteen dimensions of organizational attributes and behavior were isolated and interpreted. The factors were interpreted as follows: I. Size of Organization; II. Economic Growth; III. Tardiness vs. Family Responsibility; IV. Pay-Skill Level; V. Personnel Tenure; VI. Ownership and Concern for Organizational Interests; VII. Work-force Reduction and Job Mechanization; VIII. Technical Personnel and Controls vs. Protection Against Human Liabilities; IX. Minority Group Composition; $X$. Improvement of Working Conditions; XI. Retail Sales Personnel and Authority Conflict Behaviors; XII. Community and Employee Support rs. Work Output Restriction; XIII. Personnel Selectivity; XIV. AIlocations to Labor vs. Product Development.

The size of the firm was found to be a far greater source of variance than was the age of the firm. However, vi 
neither size nor age was appreciably related to measures of personnel performance and organizational functioning. Personnel performance and organizational functioning varied with factors that could be controlled (e.g. recreation and savings-investment programs) rather than with the enduring and unalterable conditions of an organization such as size and age.

Management tenure and experience were completely independent of other management characteristics such as age, education, pay level, and incidence of promotions. Most important, management tenure and experience were conspicuously independent of other variables, especially those involving personnel performance and organization functioning.

In regard to incentives, pay level tended to be related to worker characteristics pertaining to skill and education and was independent of personnel performance and organizational functioning. Quite the opposite held true for recreation and savings-investment programs which were essentially independent of worker characteristics, but related to a number of personnel performance and organizational functioning variables.

Following the pattern of management attributes, employee tenure was independent of other worker characteristics, especially those involving skill and education. Moreover, all the worker characteristics mentioned above were completely independent of personnel performance measures. A striking 
feature of worker characteristics was that they seemed to involve rather independent loyalties or commitments to various organizations or social groups. Furthermore, each one of these loyalties or commitments tended to be related to unique personnel behaviors.

Productivity, job aversion, and theft were mutually independent behaviors. However, job aversion behaviors split up into a number of independent components, each one being assoclated with unique conditions within the organization. Productivity was found to have no simple relationships with other variables.

A number of independent dimensions of organization functioning could be interpreted in terms of what group of organizational "participants" benefit or are effected one way or another by the organization. The interdependence of personnel performance and organization functioning was noticeably absent in many respects.

Probably the most significant aspect of this investigation is its demonstration of the complex relationships that can be expected to exist between various organizational attributes and behaviors. As more variables are taken into consideration, relationships among the original variables become altered and take on new significance. 
INTRODUCTION

In recent years much theory and consequent research on organizational behavior has been evident. However, March and Simon (1958) point out that the writings about organizations are scattered and diverse, and that the literature discloses large discrepancies between hypotheses and evidence. While the literature contains many assertions, there is Iittle data to back them up.

Approaches to Organization Theory

Organizational theory is the focus of several disciplines and conceptual schemes. Bowen (1957) remarks that the business enterprise is subject to economic, sociological, and psychological analysis. Iikewise, March and Simon (1958) note that organization theory and related empirical data stem from the following sources: the writings of executives and administrators, the scientific management movement, sociologists, social psychologists, political scientists, and economists. While all the aforementioned framework have particular advantages, the present investigation was mainly concerned with examining organizational behavior from a social psychological viewpoint as expressed by theorists such as March and Simon (1958), Haire (1959), Likert (1959), Argyris (1960), Bass (1960), and McGregor (1960). Haire (1959) comments that we find not only different 
approaches to the problem, but also different views as to the nature of the problem. For example, Argyris (1960) and Likert (1959) emphasize motivational aspects while Marschak (1959), Rapaport (1959), and Cyert and March (1959) focus on decision-making. Others such as Cartwright (1959) utilize mathematical theory, e.g., graph theory. Whyte (1959) uses an interaction approach while Bass (1960) conceptualizes organizational behavior through a broad behavioristic approach. Resfarch on this topic had traditionally been carried out through laboratory investigation, field experiments, and the intraorganizational approach.

\section{Laboratory Studies}

Laboratory investigations of the relationship between communication structure and task performance in groups have been conducted by Bavelas (1950), Leavitt (1951), Shaw (1955), and more recently by Mulder (1960). Bass (1961) has demonstrated differences in effectiveness between simulated organizations involving overlapping committee and line-staff structures. Research is currently in progress at Louisiana State University employing simulation of certain organizational features in the laboratory in order to investigate some of the problems where persons in specified roles (middle management) have to fulfill both the needs of their respective superiors and subordinates-the problem of the "man in the middle." Kennedy (1959) and Hoggatt (1959) have 
argued for the use of business games to study organizational decision-making. Although little laboratory research has been directed toward the investigation of industrial organizations per se, much laboratory research which has been conducted on small groups may be considered to have relevance to the process and perhaps particularly the unprogrammed activities of groups that occur in formal organizations. The results and implications of the numerous research studies of small groups have been summarized by Bass (1960) and Cartwright and Zander (1960).

\section{Field Experiments}

Field experiments are characterized by the actual manipulation of variables rather than just by survey and correlational analysis. Coch and French (1948) have carried out field experiments involving the effect of various types of supervision on worker performance. In general, field experiments involving organizations, especially those involving the manipulation of major variables, are quite scarce for the obvious reason of interference in organizational procedure.

\section{Intraorganizational Studies}

The intraorganizational approach has been utilized by Shartle (1956), McGregor (1960), Rubenstein (1960), Argyris (1960), and Tannenbaum, Wechsler, and Massarik (1961). These researchers' attempt to support their hypotheses by survey and correlational analysis of personnel variables 
within organizations, analysis of unit (e.g. departmental) operations, participant observation and interview findings. Examples of the correlational method, which is by far the most comon intraorganization approaches are illustrated by Baumgartel and Sobel (1959) in an investigation of the correlates of absenteeism, and by Kerr (1950) who correlates labor turnover with 24 other variables.

It should be noted that field experiments also are intraorganizational in nature. However, the generality of the findings of such experimentation and knowledge of the factors influencing the experimental variables is largely unknown. It is apparent that successful experimentation of this kind would be unlikely if attempted in organizations which were not particularly hospitable to psychological consultants and their research efforts.

Most of the current literature of research on real-life organizations has been provided by the intraorganizational approach. Such research typically involves the investigation of one or a small number of firms. Frequently, one sub-unit rather than the whole organization is examined, as exemplified by the study of Katz, Macoby, and Morse (1951) in their investigation of supervision in a specific office situation. The possibility of generalizing from such studies has been necessarily curtailed because there has been no sampling of organizations, of time periods, or control over the relevant organizational variables which would 
explain the circumstances under which relationships do or do not occur.

Organizational. Sampling Surveys

An approach which is considered more appropriate for the objectives of organizational study and which overcomes many of the mentioned limitations involves the use of sampling surveys whereby data can be gathered from a large number of organizations. Palmer (1961) examined 35 organizational survey variables pertaining to organizational conditions and personnel performance for a sample of 188 manufacturing firms in a southern metropolitan region. An analysis resulted in eight orthogonal rotated factors. The factors were identified as follows: Retirement Welfare, Cooperation with Survey, Size of Work Force, Thrift Benefits, Cost of Sickness vs. Use of Machinery, Job Aversion (e.g. lates, turnover, grievances, and complaints), Insurance Benefits and, finally Product Theft vs. Discounts on Product. Examination of the rotated factors indicated no support for Revans' (1958) notion that less favorable performance is associated with larger firms. Palmer's (1961) analysis also disclosed that productivity, job aversion, and theft were mutually independent behaviors and further that job aversion behavior was unrelated to any positive incentive conditions investigated. Each of these independent behaviors was found to be related to different organizational conditions. 
The Present Study

The purposes of the present study were as follows:

1) the isolation of various independent dimensions of organizational behavior and attributes (the identification of major sources of variance among companies) and the general relationship among variables;

2) discussing the dimensions in relation to current theory and research, especially with reference to Palmer's findings;

3) examining the relationships between organizational effectiveness, personnel performance and the extracted factors; determining the characteristics of the factors related to personal performance and organizational effectiveness.

Using Palmer's (1961) factor resolution as a guide to some of the factors, it was expected that similar as well as new factors would be uncovered in the present investigation. The comparable factors were hypothesized to differ in that more variables were expected to load on the factors extracted in the present investigation thereby changing, at least to some extent, the interpretation. Previously unidentified factors were expected because of the inclusion of more and diverse variables.

The determinants of organizational behavior are so numerous that any one research project could only hope to explore but a fraction of them. Shartle (1956) pointed out that a variety of external factors (i.e., cultural milieu, economic and social conditions) influence and interact with the internal organizational conditions with which the present analysis was concerned. Supporting Shartle's 
observation, Bowen (1957) enumerated a comprehensive list of variables that influence organizational behavior. With these thoughts in mind, the present investigation was concerned with a factor analysis of a limited number of variables. The areas investigated were as follows: company and formal organization characteristics, management attributes, incentive conditions, worker characteristics, personnel performance, and organizational effectiveness. The specific variables subsumed under each of these categories are presented in Appendix A.

It should be noted that the grouping of the variables under these six classifications is somewhat arbitrary in that some of the variables could be subsumed under more than one heading. It seems appropriate at this point to discuss briefly each classification with respect to the rationale involved in selecting the particular variables to be examined. In general, the criteria for selection were as follows: 1) relevance or importance as indicated by current theory and research, 2) facilitating factor identification by including Palmer's (1961) factor markers, 3) assessability of the information, and 4) objectivity of recording the data. It is important to realize that not all the variables considered in this study were selected to define factors and provide factor saturations, but that some of them were included as controls so that specified influences such as size and age of firm could be recognized 
and partialled out.

Sixteen of Palmer's (1961) factor marker varlables were included in the present investigation in order to extend factorial validation and the analysis of interrelationships. These 16 factor marker variables are identified in Table 3. The inclusion of more variables will as a rule increase factor identification. Consequently, Palmer's (1961) factors may be better determined and qualified in the presence of a broader range of variables. Also, in this manner, the extent of factorial invariance can be examined.

Company and Formal Organization Characteristics. Size tends to be the most important consideration here and is defined by a large number of the variables included in this section. March and Simon (1958) and Revans (1958) support the notion that personnel performance is better in smaller organizations. However, Palmer's (1961) analysis suggested that size per se had no demonstrable relationship with personnel performance.

Organization structure attributes, such as extent of departmentation, scalar stratification within management, and employee-foreman ratio, were included because there is some speculation regarding their influence on personnel performance and organizational effectiveness. In laboratory investigations Bavelas (1950), Leavitt (1951), and Shaw (1955) have shown relationships between formal communication 
channels and task effectiveness.

In regard to vertical structure, Worthy (1950) refers to the unique case of Sears, Roebuck and Company which he describes as broad or flat in contrast to the tall or vertical structures generally found. Interestingly enough, there are only four levels of supervision between the president and the salespeople in this organization of approximately 110,000 employees. Consequently, the principle of span of control was violated and decentralization was increased. According to Urwick (1944), violation of the span of control reduces efficiency. In contrast, Haire (1959) points out that the assumptions underlying the span of control are tenuous and open to investigation. The employee-foreman ratio gives us a rough indication of the size of work groups which is hypothesized to be related to various efficiency measures of group performance. Marriot (1951) states that in an automobile manufacturing concern productivity per worker decreased as size of work-group increased.

Management Attributes. The variables in this section tend to cluster around experience, education, age, and monetary reward for management. There is little doubt that these factors affect executive behavior which in turn should be related to personnel performance and especially organizational effectiveness. The importance of executive behavior in relation to effectiveness has been emphasized by Shartle 
(1956) and is given further support by the large expenditures in time, money, and effort devoted to management development by a large number of firms.

Incentive Conditions, Benefits, and Programs. The role of financial incentives in maintaining and promoting task performance was widely incorporated into the early classical organization theory. Here it was assumed that work was unpleasant and performance could only be maintained by monetary reward. Although financial incentives in relation to task performance have tended to be overemphasized (Likert, 1959; Argyris, 1960; and McGregor, 1960), it is highly probable that incentive structure is an important characteristic of organizations especially in relation to certain aspects of personnel performance (Viteles, 1953).

A large number of the variables considered here comprise various fringe benefits. The importance of fringe benefits is attested by the fact that in some instances fringe benefits comprise upwards to $20 \%$ of total wages paid and also by their importance as judged by employees and unions.

The remaining variables attempt to measure pay level, pay differentials, worker comfort, and incidence of advancement. McGregor (1960) believes that pay differentials can be a constant source of trouble; and Ghiselli and Brown (1948) suggest that whenever management introduces programs 
to Increase worker comfort, safety, and satisfaction, such programs lead in the long run to higher profits.

Worker Characteristics. Much theory and research has been concerned with the human element, especially the relationship between characteristics of the work group and measures of personnel performance. The vartables included here attempted to define the following characteristics of the worker: skill level, age, ethnic and religlous background, education, unionization, and sex. Morse (1953) found a negative relationship between skill level and voluntary turnover. March and Simon (1958) hypothesize lower turnover among minority groups while Myers and MacLauren (1943) present evidence for high turnover for males than for females. Van Zelst (1954) presents evidence that accident rates decrease with age. Blau (1957) suspects that the lack of work groups on the assembly line might result in stronger union identification and higher turnover and absenteeism. In one respect, these variables can be looked upon as providing general measures of personnel homogeneity whose importance in relation to effective group behavior has been emphasized by Likert (1958) and Bass (1960).

Personnel Performance. Personnel performance, along with organizational effectiveness, are usually thought of as two groups of criterion measures. Thorndike (1949) regards them as intermediate and ultimate criteria respectively. 
Personnel performance measures have been traditionally used as criteria in industrial studies investigating their relationship with other factors in the industrial complex. The previous section contains examples of such relationships.

The personnel performance measures center around such indices as accidents, turnover, grievances, lateness, production, equipmemt maintenance, advancement requests, theft, work stoppage, and management-worker conflict. Palmer's (1961) analysis indicated job aversion (lates, turnover, grievances, etc.), production, and theft to be mutually independent work behaviors. He interpreted these results in support of Herzberg, Mausner, and Synderman's (196I) twocomponent hypothesis that productivity tends to be associated with positive incentives while job aversion may be related to independent dissatisfiers. Palmer's (1961) analysis did not disclose what these dissatisfiers were. Castle (1956) found support of the theory that one factor contributes to the cause of accidents and desire to withdraw from the work situation. In a review of the literature, Brayfield and Crockett (1955) found no consistent relations among measures of production, absences, and voluntary turnover. It will be interesting to examine the organization conditions associated with these hypothesized independent cluster of personnel performance. Part of the rationale for including performance measures is their expected facilitation in identifying "Important" correlates of personnel and 
organizational functioning.

Organization Effectiveness. Bass (1952) and others have proclaimed that the ultimate criteria of organizational worth shou?d be expanded to include the worth of the organization both to the worker and society as well as its worth in terms of productivity and profits. This was kept in mind in the selection of variables to measure organizational effectiveness. An attempt was made to include various measures of growth (a number of which are related to economic growth in one way or another), contributions to society, efficiency, and attractiveness. Support for including some of the variables purporting to measure effectiveness is given by Dent (1959) who through executive interviews concluded that the aims of management were, in part, to make money, pay dividends, grow, and stay ahead of competitors. Again, it is of interest to examine the dimensions that are related to organizational effectiveness. Of particular interest are the relationships disclosed between the two classes of measures concerned with personnel and organizational functioning. 
PROCEDURE

Questionnaire

A multiple choice questionnaire containing 84 items pertaining to the six areas of organizational attributes and behavior discussed previously was developed and pretested on a sample of local manufacturers. The 84 variables grouped under the six categories are presented in Appendix A.

\section{Sample Survey}

A representative sample of 2,938 manufacturing firms residing throughout the continental United States was developed. The number of firms selected from each state was based on the proportion of manufacturing in the respective states according to the 1961 U.S. Statistical Abstracts. However, within each state the firms were drawn at random from the appropriate state directory of manufacturers. With each questionnaire was sent an explanatory covering letter, a postage-paid return envelope, and two IBM mark-sense cards for recording answers as detailed in the appendix. Each company was offered a free summary report if they desired one. The participating firms were assured that all information would be kept confidential.

Reliability of Reports

A sample of 200 original respondents was retested in 
order to check the consistency of answering the items. This second request, again conducted by letter, asked companies to help in verifying the accuracy of our records. A copy of this letter may be found in Appendix E.

\section{Nonresponse}

A random sample of 300 nonrespondents was requestioned by letter in order to gain an indication of the direction of nonresponse bias. A copy of the letter directed to the nonrespondents can be found in Appendix F. Originally it was intended that differences in the proportions between followup and original respondents would be computed and a bias scale constructed from these differences correlated with the loadings on each factor. But due to the small response (28) of the follow-up sample, the procedure was modified. The direction and magnitude of the differences in the proportions (based on median cuts of the original distribution) between follow-up and original respondents were visually examined for relationships with both the significant loadings on each factor and the six categorles of organizational attributes and behavior.

\section{Data Analysis}

For this analysis it was assumed that linear regressions accounted for a major proportion of the variance, even though some regressions would be expected to involve more complex functions. Accordingly, Pearson linear product moment 
correlations were utilized to compute the intercorrelations between the 84 variables. Where some respondents reported no information for some questions, correlations among the variables were based upon the number of cases common to each pair of variables. The $\mathrm{N}$ for the correlations ranged from 66 to 232. However, the majority of the correlations were based on an $N$ of 180 or more and in only four instances were the correlations based on an $N$ of less than 100 .

The 3,486 correlations were subjected to a principal components analysis (Hotelling, 1933) and rotated to nearly orthogonal, simple structure by the varimax method (Kaiser, 1958). The decision to stop factoring was based upon the diminishing contributions to the total variance of the successively extracted factors. 


\section{RESULTS}

\section{Returns}

Elght percent (234) of the 2,938 questionnaires were returned. The distribution of the returns, classified according to type of product manufactured and geographical location, are shown in Tables 1 and 2 respectively. Appendix A discloses the frequency distribution of the options selected for each of the 84 items. The Iow percentage of returns is attributed in part to the length of the questionnalre, the reluctance to reveal certain information, and the low pulling power of a general appeal by letter.

\section{Rellablilty of Reports}

Thirteen percent (26) of the 200 firms retested for consistency responded. On this basis reliability coefficients were computed. The reliability for each 1tem is shown in Table 3. The average reliabllity coefficient for the 84 variables was .73. Under Spearman-Brown assumptions for a sample approximately 9 times as large, the average reliability was .96. It should be noted that the rellability coefflclents were not altogether adequate measures of the consistency of reporting. The proportion of agreement was quite high, but because of little or no variance in one or both of the distributions a number of the corresponding 
TABLE 1

RETURNS BY PRODUCT CLASSIFICATION ${ }^{a}$

$(\mathrm{N}=234)$

\begin{tabular}{|c|c|c|c|}
\hline Product Class & $\begin{array}{l}\text { Percent of } \\
\text { Returns }\end{array}$ & \multicolumn{2}{|c|}{$\begin{array}{l}\text { Percent in Actual } \\
\text { Populationb }\end{array}$} \\
\hline $\begin{array}{l}\text { Fabricated Metals } \\
\text { Food } \\
\text { Non-Electrical Machinery } \\
\text { Printing and Publishing } \\
\text { Stone, Clay, and Glass } \\
\text { Primary Metals } \\
\text { Lumber } \\
\text { Chemical and Allied } \\
\text { Furniture } \\
\text { Apparel } \\
\text { Electrical Machinery } \\
\text { Miscellaneous } \\
\text { Textiles } \\
\text { Paper and Allied Products } \\
\text { Petroleum } \\
\text { Leather } \\
\text { Transportation Equipment } \\
\text { Rubber and Plastics } \\
\text { Scientific and Control Instru- } \\
\text { ments } \\
\text { Tobacco } \\
\text { ToTAL }\end{array}$ & $\begin{array}{r}16.7 \\
13.7 \\
10.3 \\
7.7 \\
7.7 \\
6.0 \\
5.6 \\
5.6 \\
3.8 \\
3.4 \\
3.0 \\
3.0 \\
2.6 \\
2.1 \\
2.1 \\
2.1 \\
1.7 \\
1.7 \\
.9 \\
100\end{array}$ & $\begin{array}{l}\text { not } \\
\text { not }\end{array}$ & $\begin{array}{l}7.7 \\
14.8 \\
\text { available } \\
11.3 \\
\text { available } \\
2.2 \\
14.5 \\
3.9 \\
3.6 \\
10.9 \\
\text { available } \\
5.1 \\
2.8 \\
1.7 \\
.4 \\
1.7 \\
1.9 \\
1.3\end{array}$ \\
\hline
\end{tabular}

$a_{\text {This is the standard industrial classification as given }}$ by the Bureau of the Budget in 1957.

b. These percentages are based on the U.S. Statistical Abstracts (1961). 
TABLE 2

RETURNS BY GEOGRAPHIC LOCATION $(N=234)$

\begin{tabular}{lcc}
\hline Geographic Iocation & $\begin{array}{c}\text { Percent of } \\
\text { Returns }\end{array}$ & $\begin{array}{c}\text { Percent in Actual } \\
\text { Populationa }\end{array}$ \\
\hline New England & 8.1 & 8.6 \\
Middle Atlantic & 16.2 & 28.7 \\
East North Central & 26.9 & 20.6 \\
West North Central & 8.9 & 6.6 \\
South Atlantic & 11.5 & 10.6 \\
East South Central & 3.0 & 4.5 \\
West South Central & 5.2 & 5.7 \\
Mountain & 4.7 & 2.3 \\
Pacific & 15.3 & 12.3 \\
\hline
\end{tabular}

$a_{\text {These percentages are based on the U.S. Statistical }}$ Abstracts (I96I). 


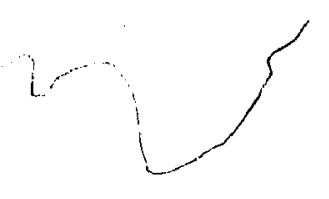

TABLE 3

REIIABILITIES FOR ORIGINAL RESPONDENTS AND PROPORTIONS FOR ORIGINAL AND NONRESPONDENT RETURNS ${ }^{a}$

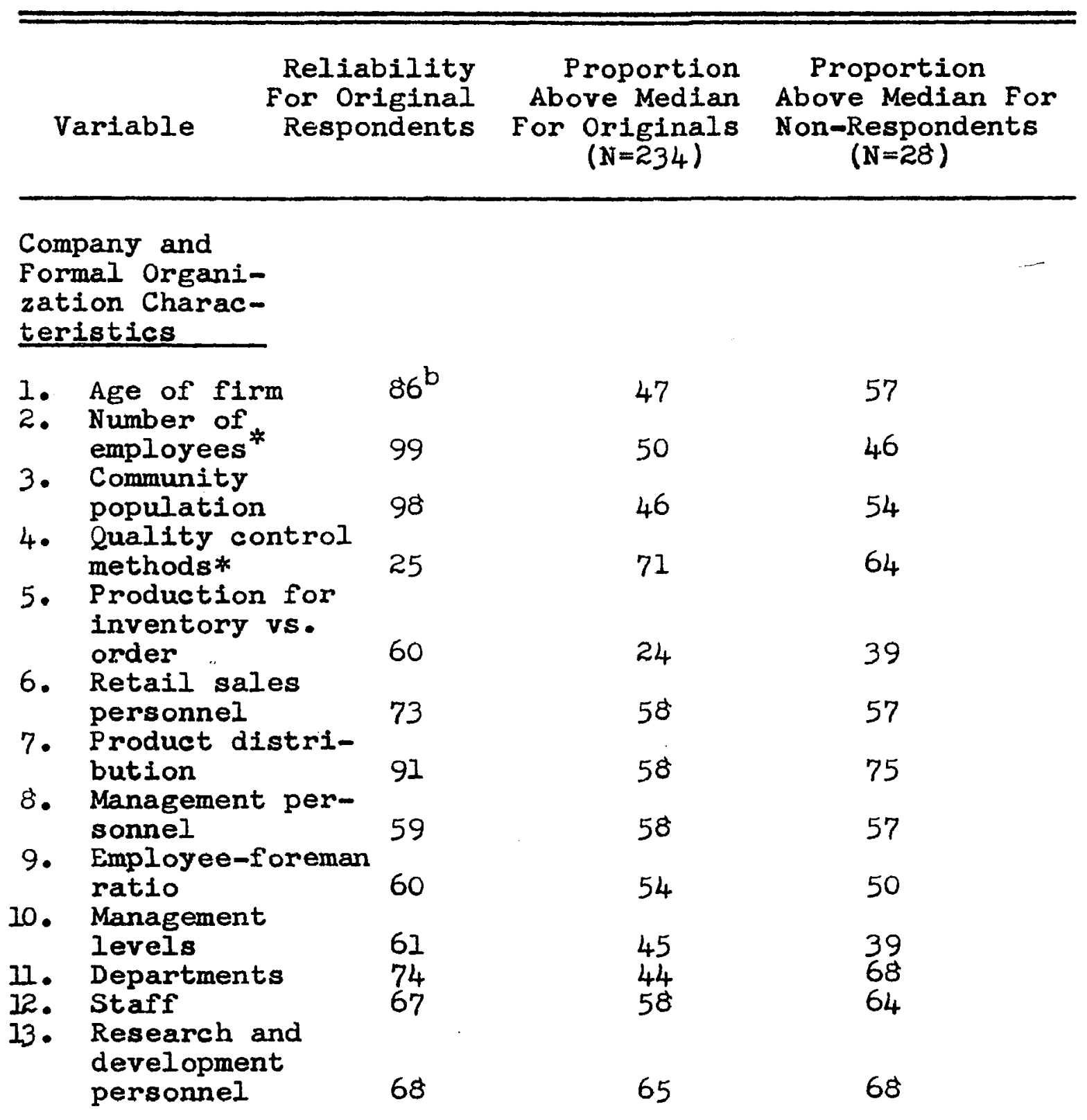


TABLE 3 cont'd.

\begin{tabular}{ccc} 
Reliability & $\begin{array}{c}\text { Proportion } \\
\text { For Original } \\
\text { Respondents }\end{array}$ & $\begin{array}{c}\text { Proportion } \\
\text { For Originals } \\
(N=234)\end{array}$ \\
\hline
\end{tabular}

Management

Attributes

14. Management payment plans 75

15. Management tenure 87

87

64

57

16. Sub-management tenure 88

47

64

17. Managerial experience

50

36

18. Management pay

19. Management

57

48

43

stockholders 86

56

64

20. Management

53

54

education

87

58

61

21. Management pay level

55

43

22. Management age 78

$60 \quad 75$

23. Committee meetings

90

61

75

24. Management Promotion from within

52

75

Incentive Conditions,

Programs, and Bene-

fits

25. Plant worker pay level 85

$47 \quad 46$

26. Office worker pay level

67

$50 \quad 54$

27. Community pay rates

80

52

57

28. Recreational facilities* 
TABLE 3 Cont'd.

\begin{tabular}{cccc}
\hline & $\begin{array}{c}\text { Reliability } \\
\text { For Original } \\
\text { Respondents }\end{array}$ & $\begin{array}{c}\text { Proportion } \\
\text { For ore Median }\end{array}$ & $\begin{array}{c}\text { Proportion } \\
\text { Above Median For } \\
(N=234)\end{array}$ \\
\hline
\end{tabular}

29. Pay differential for production

30. Perkiors program* 51

31. Group Insurance ${ }^{*} 100$

32. Savings-investplan* 58

33. Sick pay* 100

34. Discount * 93

35. Cost of fringe benefits 73

36. Pay increases 61

37. Promotions 65

38. Working conditions

81

15

07

51

79

57

53

64

49

58

57

52

50

Worker Characteristics

\begin{tabular}{|c|c|c|c|c|}
\hline & \multirow{2}{*}{$\begin{array}{l}\text { Stockholders } \\
\text { Hourly paid } \\
\text { workers } \\
\text { Employees trav- }\end{array}$} & $7 I$ & 30 & $2 I$ \\
\hline & & 64 & 63 & 57 \\
\hline 41. & $\begin{array}{l}\text { Employees trav- } \\
\text { elling } 10 \text { or mor } \\
\text { miles to work }\end{array}$ & 81 & 50 & 46 \\
\hline 42. & $\begin{array}{l}\text { Catholic employ- } \\
\text { ees }\end{array}$ & 96 & 48 & \\
\hline $\begin{array}{l}43 . \\
44 .\end{array}$ & $\begin{array}{l}\text { Machine operator } \\
\text { American-born }\end{array}$ & 85 & 55 & 57 \\
\hline & white Christians & 87 & 37 & 43 \\
\hline $\begin{array}{l}45 . \\
46 .\end{array}$ & $\begin{array}{l}\text { Union members* } \\
\text { High school }\end{array}$ & 96 & 62 & 79 \\
\hline & graduates & 81 & 43 & 46 \\
\hline $\begin{array}{l}47 . \\
48 .\end{array}$ & $\begin{array}{l}\text { Worker tenure } \\
\text { Male workers }\end{array}$ & $\begin{array}{l}88 \\
82\end{array}$ & $\begin{array}{l}41 \\
52\end{array}$ & $\begin{array}{l}50 \\
35\end{array}$ \\
\hline 49. & $\begin{array}{l}\text { Workers married } \\
\text { with } 2 \text { or more }\end{array}$ & & & \\
\hline & children & 80 & 47 & \\
\hline & Skilled laborers & 75 & 50 & 50 \\
\hline 51. & $\begin{array}{l}\text { Worker age } \\
\text { Negro Employees }\end{array}$ & $\begin{array}{l}91 \\
84\end{array}$ & $\begin{array}{l}39 \\
61\end{array}$ & $\begin{array}{l}08 \\
64\end{array}$ \\
\hline
\end{tabular}


TABLE 3 Cont'd.

\begin{tabular}{|c|c|c|c|}
\hline Variable & $\begin{array}{l}\text { Reliability } \\
\text { For Original } \\
\text { Respondents }\end{array}$ & $\begin{array}{l}\text { Proportion } \\
\text { Above Median } \\
\text { For Originals } \\
(\mathrm{N}=234)\end{array}$ & $\begin{array}{l}\text { Proportion } \\
\text { Above Median For } \\
\text { Non-Respondents } \\
\quad(N=28)\end{array}$ \\
\hline
\end{tabular}

Personnel Performance

53. Mack.ine down

$\begin{array}{llll}\text { time } & 77 & 45 & 36\end{array}$

54. Accidental damage to plant or equipment 63

55. Strikes, etc. 00

56. Substandard production* 77

57. Absentees* 58

58. Grievances* 79

59. Turnover* 55

60. Lates (p.m.)* 88

61. Theft* 24

3

62. Superiorsubordinate conflicts

63. Accidents 90

64. Discharges 78

65. Lates $\left(a . m_{.}\right) * 89$

66. Promotion requests 92

67. Pay requests 58

68. Personality problems

60

93

51

57

68

46

61

57

66

61

$66 \quad 6 I$

Organizational Function

69. Jobs eliminated 84

70. New products 86

78

75

54

58

65

54

46

54

65

49

57

59

54

71

71. Civic contributions

71

63

72

$50 \quad 43$

72. Selection ratio 89

47

32

$50 \quad 39$

73. Customer complaints

74

55

54

74. Dividends (increase or decrease)

50

57

75. Applicants (increase or decrease)

62

49

50 
TABLE 3 Cont'd.

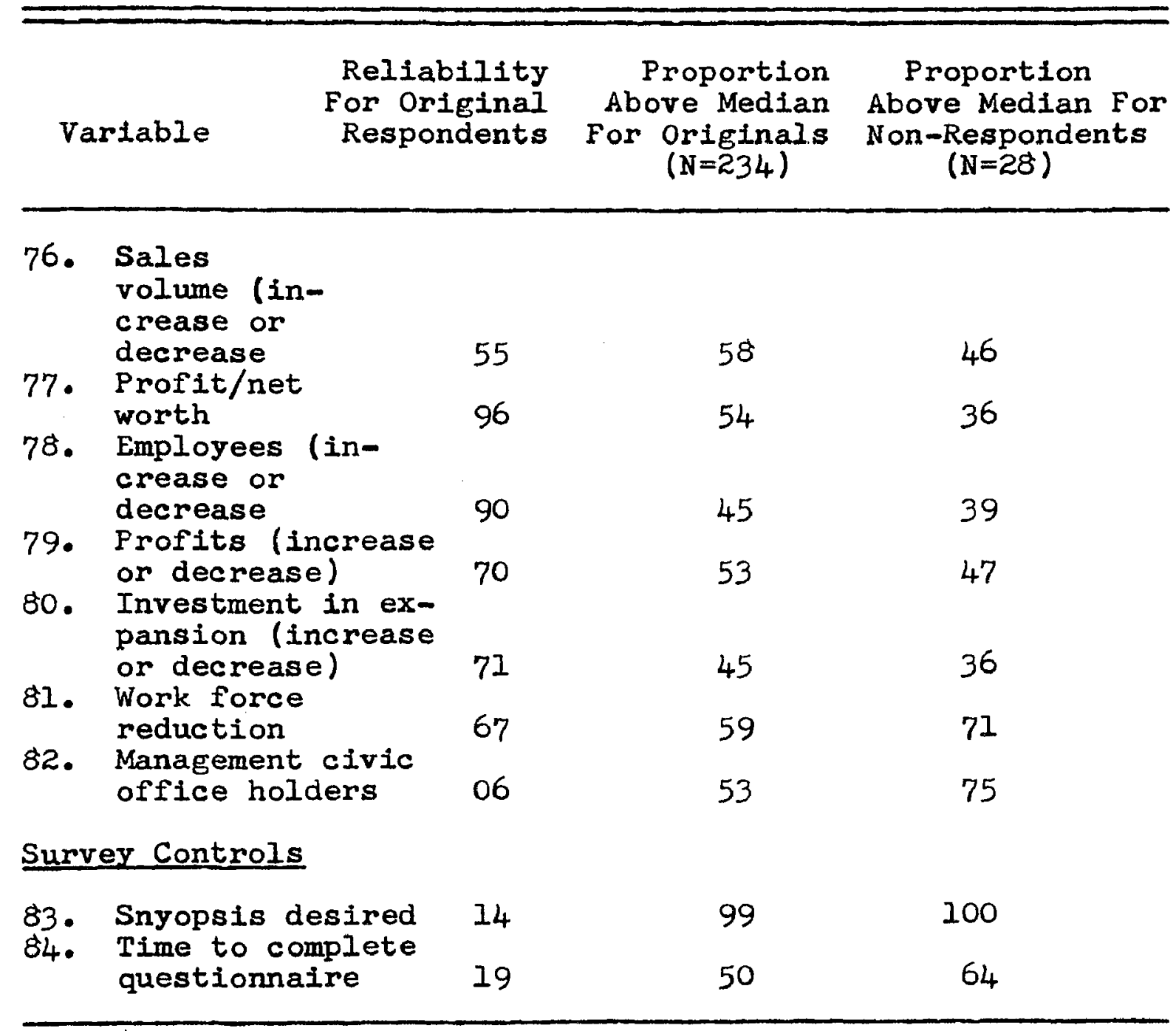

aThe proportions for both original and nonrespondents are based upon cuts made at the median of the original distribution. The proportions presented are those lying above the median in the direction of the smaller options.

$b_{\text {Decimals are omitted. }}$

*These variables were factor markers in Palmer's (1961) analysis. 
rellability Indices were low.

\section{Nonresponse Blas}

Information was obtained from 9 percent (28) of the 300 nonrespondent companies in the call-back sample. Table 3 compares the response of each item for these 28 companies with the original 234 respondents. The proportions arrived at were based on median cuts made on the distributions of the original returns. Those proportions shown in Table 3 are the proportions above the median (the lower numbered options). No statistical analyses were performed, but visual inspection of the direction of the differences in proportions seemed to indicate that orlginal respondents tended to give more favorable reports in regard to personnel performance, incentive conditions, and various attributes of both workers and management such as skill, education, and tenure. Original respondents tended to give somewhat less farorable reports of economic growth. Consequently, some blas has probably influenced those factors whose variance was primarily contributed to by the above mentioned sources. However, the extent of the influence of nonresponse bias was not disclosed.

\section{Factors}

The Pearson product moment correlations between the 84 variables, the final rotated factor matrix, and the factor intercorrelation matrix are deposited with the Loulsiana 
State University Iibrary. Table 4 shows the significant loadings (.30 or greater) on all factors grouped according to the previously presented classification scheme. Some of the loadings in Table 4 are reflected for consistency so that the positive sign of a loading indicates the presence of higher magnitudes of a variable. The rotated factors are presented in descending order of common factor variance accounted for. The percentage of common variance accounted for by each factor is shown in Table 4.

The first 14 unrotated factors extracted accounted for 54 percent of the total variance. Factor I accounted for 16.6 percent of the total variance while Factor XIV only contributed 1.8 percent of the total variance. In general, the examination of the 84 Lambdas suggests much specificity in the original intercorrelation matrix. After these 14 factors were rotated, It was found that Factor I accounted for 26.7 percent of the comon variance while the remaining 13 factors contributed from 7.9 to 3.8 percent of the comon varlance. The rotated factors were nearly orthogonal, the correlations between factors ranging from .00 to .35 . However, only two of the 91 intercorrelations were above .20. In interpreting and discussing the factors, it should be kept in mind that the results of the present study need not necessarily agree with investigations conducted within companies and that furthermore it is impossible to answer questions pertaining to temporal or casual relationships 
Company and Formal

Organizatton Gharacteristics
Management Attributes
Incentive Conditions, Benefits, and Programs

\section{Size of Organization $(27 \%)^{2}$}

$\begin{array}{ll}\text { 2. Employees (NO.) } & .92 \\ \text { 11. No. of departments } & .73 \\ \text { 9. Employee - foreman ratio } & .70 \\ \text { 10. No. of vertical levels } & .67 \\ \text { 13. Research \& development } & .56 \\ \text { personne1 (NO.) } & \\ \text { 7. Product distribution } & .47 \\ \text { 1. Age of firm } & .31\end{array}$

$\begin{array}{ll}\text { 24. Promotions from within (NO.) } & .87 \\ \text { 20. Co1lege graduates (NO.) } & .75 \\ \text { 22. Age (NO. 50 yrs. of age or } & .71 \\ \text { older) } & .65 \\ \text { 23. Committee meetings (NO.) } & .62 \\ \text { 21. Pay over 15,000 (NO.) } & .60 \\ \text { 18. Pay differential } & .59 \\ \text { 19. Stockholders (NO.) } & \end{array}$

35. Cost of fringe benefits

30. Pension

36. Pay increases (\%)

37. Promotions (\%)

31. Group insurance

28. Recreational facilities

33. Sick pay

II. Economic Growth (8\%)

III. Tardiness vs, Family

Responsibility (7\%)

IV. Pay - Skill Leve1 (7\%)

\begin{tabular}{lc} 
25. Plant workers earning & .79 \\
over $\$ 400$ (No.) & \\
26. Office workers earning & .76 \\
$\begin{array}{l}\text { over } \$ 350 \text { (No.) } \\
\text { 31. Group insurance }\end{array}$ & .32 \\
35. Cost of fringe benefits & .32 \\
\hline
\end{tabular}

V. Personne1 Tenure (7\%)

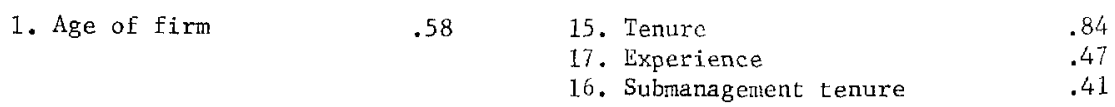

VI. Ownership and Concern for

Organizational Interests (5\%)
19. Stockholders
(No.)
.30

VII. Workforce Reduction and Job Mechanization (5\%)

5. Production for inventory vs. order

VIII. Technical Personnel and Controls vs. Protection Against Human Iiab1lities $(5 \%)$
12. Staff (\%)
4. Quality control

IX. Minority Group Composition (5\%)

3. Conmunity population $\quad .33$ 


\begin{tabular}{|c|c|c|c|c|}
\hline $\begin{array}{l}\text { 39. Stockholders }(\%) \\
\text { 45. Union members }(\%)\end{array}$ & $\begin{array}{l}.32 \\
.36\end{array}$ & $\begin{array}{l}\text { 57. Absentees (NO.) } \\
\text { 63. Accidents (NO.) } \\
\text { 64. Discharges (NO.) } \\
\text { 58. Grievances (\%) } \\
\text { 54. Damage to plant (\$) } \\
\text { 68. Personality problems (NO.) } \\
\text { 55. Strikes, etc. (NO.) } \\
\text { 61. Theft (No.) } \\
\text { 66. Promotion requests (\%) }\end{array}$ & $\begin{array}{l}.76 \\
.67 \\
.58 \\
.49 \\
.48 \\
.46 \\
.43 \\
.34 \\
.30\end{array}$ & $\begin{array}{l}\text { 69. Jobs eliminated (No.) } \\
\text { 73. Customer complaints (No.) } \\
\text { 75. Applicants (\% increase) }\end{array}$ \\
\hline
\end{tabular}

57. Absentees (NO.)

63. Accidents (NO.)

64. Discharges (No.)

Grievances $(\%)$

55. Strikes, etc. (NO.)

66. Promotion requests (\%)
.36 age or older)
.38
.41

60. \% lates (p.m.)

65. \% lates (a.m.)

67. Pay requests $(\%)$

58. Grievances $(\%)$

56. Substandard production (\%)
53. Machine down time
79. Profits (\% increase or decrease) $\quad .87$

76. Sales (\% increase or decrease) .81

78. Employees (\% increase or decrease) .73

74. Dividencis (\% increase or decrease) .63

77. Profit/net worth .47

75. Applicants (\% increase or decrease) .44

8n. Expansion (\% increase or decrease) .44 children (NO.)

$\begin{array}{ll}\text { 50. Skilled laborers (\%) } & .58 \\ \text { 48. Male (\%) } & .36 \\ \text { 46. High school graduates (\%) } & .36 \\ \text { 45. Union members (\%) } & .33 \\ \text { 41. Trave1 } 10 \text { or more } & .32\end{array}$

45. Union members (\%) .33 miles to work $(\%)$ 
IV. Pay - Skill Level (7\%)

$\begin{array}{ll}\text { 25. Plant workers earning } & .79 \\ \text { over } \$ 400 \text { (No.) } & \\ \text { 26. Office workers earning } & .76 \\ \begin{array}{l}\text { over } \$ 350 \text { (No.) } \\ \text { 31. Group insurance }\end{array} & .32 \\ \text { 35. Cost of fringe benefits } & .32\end{array}$

\section{Personnel Tenure ( $7 \%$ )}

1. Age of firm

$\begin{array}{ll}.58 & \text { 15. Tenure } \\ \text { 17. Experience } & .84 \\ \text { 16. Submanagement tenure } & .47 \\ & \end{array}$

Vx. Ownership and Concern for

Organizational Interests $(5 \%)$

19. Stockholders (NO.) .30

VII. Workforce Reduction and

Job Mechanization (5\%)

5. Production for inventory vs, order $-.43$

34. Discount (\%)

VIII. Technical Personnel and Controls vs. Protection Agalnst Human Liabilities (5\%)
12. Staff $(\%)$
$-.67$

4. Quality control

$-.57$

31. Group insurance

IX. Minority Group Composition (5\%)

3. Community population .33

X. Improvement of Working Conditions (47)

Research and development personnel (No.) .33

38. Improvement of working conditions $(\$)$ .75

XI. Retail Sales Personnel and Authority Conflict Behaviors (4\%)

6. Retail sales force (No.) .70

7. Product distribution $\quad-.31$

XII. Community and Employee

Support vs. Work Output

Restriction (4\%)

7. Product distribution

.32

16. Submanagement tenure

.31

28. Recreational facilities

32. Savings investment
$-.41$ $-.39$

\section{PersonneI Selectivity (4\%)}


49. Married and 2 children (NO.)
.41

60. \% 1ates (p.m.)

65. \% lates (a.m.)

67. Pay requests $(\%)$

58. Grievances (\%)

56. Substandard production $(\%)$

53. Machine down time
.86

.71

.40

.37

.31

.30

50. Skilled 1aborers (\%)

48. Male (\%)

46. High school graduates (\%)

45. Union members (\%) .33

41. Travel 10 or more .32 miles to work $(\%)$

47. Tenure

51. Age
.73

.51
59. Turnover $(\%)$

.32
39. Stockholders (\%)

.40
54. Damage to plant and equipment (\$)

67. Pay requests (\%)

53. Machine down time
73. Customer complaints (NO.)

$-.36$

39. Stockholders (\%)

62. Superior-subordinate conflict (No.) 61. Theft (No.)

82. Management civic contributions

(No. of office holders)

Survey control

83. Synopsis desired

52. Negroes (\%)

.77

christians (\%)

$-.77$

43. Machine operators $(\%)$

$-.35$

.49

.44
43. Machine operators (\%)

42. Catholics (\%)
$-.38 \quad 66$. Promotion requests $(\%)$

55. Strikes, etc. (No.)

56. Substandard production (\%)

.36 71. Civic support (\$)

.53

.31 75. Applicants (\% increase or decrease) -.37

82. Management civic contribution

(No. of office holders)

$-.31$

$.43 \quad 72$. Selection ratio

$-.69$ 
among the varlables included in this investigation.

It seems appropriate at this point to discuss some of the considerations adhered to in the interpretation of the factors. The majority of the items were defined in terms of either absolute numbers or percentages. Therefore, in most instances, only measures based on percentages can be meaningfully related to size and other varlables associated with size. It was expected, for example, that larger firms would have a greater number of absentees. In general, the magnitude, range, and order of the loadings were considered in the interpretation of the factors. When a factor was characterized by one or a few high loadings and a number of small loadings, the higher loadings were given more emphasis in the interpretation. Also, when the factor structure was such that the majority of the loadings were of the same magnitude, each loading was given equal attention in the interpretation.

In discussing the factors some attention was focused on the negative as well as the positive implications of various factors. Relationships that were conspicuously absent were pointed out.

Factor I. S1ze of Organization. The variables that load significantly on Factor I seem to be indicative of the size of the organization. Larger firms are able to offer more in the way of recreation, retirement, and insurance 
programs than smaller firms. Furthermore, larger firms offer more opportunities for promotions and pay increases. There is an interesting implication in the relationship between size of firm, percentage of employees owning stock, and the percentage of union members. In line with the March and Simon (1958) analysis, the implication is that in larger firms there tends to be a greater incidence of overlapping roles. In this instance, the overlapping is between the role of union member and the role of plant owner. Moreover, these roles are in conflict with one another in that aims of the union are in many instances contraxy to the aims of the owner.

The volume of personnel behaviors such as absenteeism, accidents, discharges, behavior problems, and theft is highly related to size as would be expected on the basis of item definitions. However, there is no evidence to indicate that these performance measures are disproportionately related to size lending no support to Revans' (1958) conclusion that generally less favorable performance is associated with size. It should be noted that job aversion behaviors such as lates and turnover were completely independent of size.

As expected, company and formal organization characteristics such as number of departments, number of vertical levels, and number of personnel in research and development were highly related in a positive direction to size due again to item definitions. The same is true of the following 
management attributes: number of stockholders, number of college graduates, number over 50 years of age, number promoted from lower levels within, and number earning over $\$ 15,000$ per year.

Larger firms experience more strikes, etc. and a higher percentage of worker grievances than do smaller firms. A partial explanation for this relationship might be found in the increased union activity in the larger firms.

The structure of this factor also suggests that larger firms tend to be more attractive to job seekers as indicated by the percentage increase in applicants. This observation lends support to March and Simon (1958) who contend that larger firms are more visible and therefore more likely to attract applicants.

Factor II. Economic Growth. This factor 1s characterized by growth primarily in the economic sphere of industrial functioning. The rather low relationship between employee age and the cluster of growth variables implies that firms with older workforces experience less economic growth.

It is important to note that organizational growth is independent of size, management education and experience, employee skills and performance, and all the other organizational variables considered. It would seem highly probable, because of the many internal conditions examined here, that conditions external to the organization play a substantial 
role in the organizational growth of a business enterprise.

Factor III. Tardiness vs. Family Responsibility. The positive pole of Factor III is substantially related to the incldence of morning and afternoon lates and the negative pole moderately related to the percentage of employees who are married with two or more children. This observation suggests that workers with family responsibilities are less likely to exhibit Irresponsibility on the job at least in respect to reporting late.

This factor is somewhat similar to Palmer's (1961) Job Aversion factor in that aversive behaviors (primarily lates) accounted for the majority of the factorial variance. However, Palmer (1961) found turnover and absences loading on the same factor as lates while the present analysis disclosed them independent of lates. This discrepancy was probably due to the increased coverage of variables and their resultant influence on the decomposition of the performance variables.

Eactor IV. Par-Skill Level. Various incentive conditions (primarily pay level) and worker characteristics (skill, sex, and education) covary together contributing essentially all of the factorial varlance to this factor. This factor exemplifies the comon observation that jobs requiring education and skill are more hlghly rewarded than 
those that do not. Except for the population of the firm's community, these two clusters are markedly independent of variables in the remaining classifications. Especially interesting is the lack of relationships between these particular Incentive conditions and worker characteristics, and measures of personnel performance and organizational effectiveness, which tends to support contentions by Iikert (1959), Argyris (1960), and MeGregor (1960) that financial incentive conditions in relation to task performance have tended to be overemphasized. An implication here is that money buys skills, but not necessarily better performance.

Fastor V. Personnel Tenure. The observation that both management and worker tenure are highly interdependent supports the notion that, in general, firms have attractions which transcend all levels of employment. Besides the expected inverse relationship with turnover, tenure is conspicuously independent of all other considerations. It is of particular interest to note that tenure is independent of incentive conditions, particularly those involving retirement benefits which would be expected to be especially effective in prolonging tenure. A complication arises here in that it is not known whether this turnover is primarily roluntary or involuntary in origin. The conmon notion that firms comprised of older workforces experience less turnover is given some support. 
FACTOR VI. Ownership and Concern for Organizational Interests. The negative pole of this factor reflects dissatisfaction with pay, lack of concern for plant and equipment, and customer dissatisfaction, while the positive pole reflects personal involvement of both management and employees as evidenced by stock ownership. The significant result here is that stock ownership is related to those performance measures that involve direct cost reduction or malntalning the goodwill of the clientele. A valuable conclusion to be drawn from this factor is that employees with ownership roles cooperate toward some important goals by essentially protecting their own investments. Relationships such as that found for this factor have important implications for labor relation policles. For example, management might try through various means (e.g. stock purchase plans) to encourage their employees to invest in their firm's stock. This factor is significant in that stock ownership fosters behaviors that are not assoclated with any other type of personnel benefit or remuneration.

Factor VII. Workforce Reduction and Job Mechanization. This factor suggests that firms manufacturing for inventory are more likely to reduce their workforce and number of jobs as a consequence of automation or mechanization. Production for inventory rather than for other makes it possible to schedule and stabilize production thereby taking advantage 
of the economies of mechanization. The low loading of dividends indicates an interesting tendency toward increased dividend payments as labor displacement takes place.

Factor VIII. Technical Personnel and Controls vs. Protection Against Human Liabilities. One pole of this factor emphasizes the use of technical specialists and procedures while the other pole indicates the presence of group insurance programs. The interpretation of this factor is not clear cut. One interpretation might be that organizations attempt to insure themselves against contingencles that cannot be coped with by technological specialists. Another suggested interpretation is that technical personnel and controls along with insurance are two ways of handling two kinds of problems: technology and technical specialists for monltoring controllable productive processes; and insurance for controlling the unpredictable liablities of personnel disability. This factor is somewhat similar to Palmer's (196I) Costs of Sickness vs. Use of Machinery factor which was characterized by the presence of health provisions and quality control methods.

Factor IX. Minority Group Composition. This factor primarily reflects the presence of minority groups in the working force. The extent of minority group composition (primarily Negroes) tends to be inversely related to the percentage of machine operators in the workforce and 
positively related to the size of the community in which the firm is located. Except for the above relationships, the presence of minority groups in the workforce is independent of any other variables. Noticeably absent are relationships between minority groups and various personnel performance measures, especially turnover which March and Simon (1958) hypothesize to be lower among minority groups. Also, contrary to what might have been expected, the extent of minority group composition was not found to be related to such worker characteristics as education and skill level, and incentive conditions such as pay level and the presence of fringe benefits.

Factor x. Improvement of Working Conditions. Improvement of working conditions loads substantially on this factor while substandard production and the number of people involved in research and development load slightly in the same direction. This factor pattern is not clear cut, but It is possible that the existence of substandard production has in part prompted research and development and the improvement of working conditions.

\section{Factor XI. Retail Sales Personnel and Authority Con-} flict Behaviors. The incidence of theft and superiorsubordinate conflict is more frequent in those firms characterized by larger retail sales forces and local product distribution. It is quite possible that a large number of 
superior-subordinate conflicts revolve around theft situations. Palmer's (196I) finding that amount of product discount was inversely related to the incidence of theft was not disclosed in the present analysis, but his finding that theft was an independent dimension of behavior was confirmed.

Factor XII. Community and Employee Support ys. Work Output Restriction. The general picture is that of an organization which offers benefits to employees through recreation and savings-investment programs, and to the local community through monetary contributions and management participation in charitable and civic organizations. Organizations fulfilling this description experience fewer work stoppages and less substandard production relative to other firms. Such organizations are also more likely to experience an increased percentage of applicants. This factor is interesting because it is one of the few factors to suggest a direct relation between personnel benefits and productivity, although the magnitude of the relationship is low.

Factor XIII. Employee Selectivity. The implication here is that firms paying better wages enjoy a more favorable selection ratio. Also, such firms are characterized by a higher incidence of promotion requests and a lower percentage of Catholic workers. 
Factor XIV. Allocat1ons to Labor Yg. Product Development. FIrms that are composed of hourly workers are more likely to grant pay increases and less likely to introduce new products in their product line. It should be noted that new product means products new to a particular firm but not necessarily new to industry at large. Although the meaning of this factor is not clear, one suggestion is that investment is made in worker wages rather than in the development of new products. 


\section{DISCUSSION}

In this section, the factor structure for each one of the six categories of organizational attributes and behavior will be presented. The parentheses following each dimension enclose the factor from which the particular dimension was drawn. Also, some of the more significant cross relationships among these six categories will be examined. The primary pumpose here 1s to discuss some relationships and implications that were not brought out by the interpretation of the individual factors in the result section.

Company and Formal Organization Characteristics

This category is composed of the following eight relatively independent dimensions: size of organization (I), community population (IV), age of firm (V), production stabilization (VII), technological services and controls (VIII), research and development (X), retall sales force $(X I)$, and product distribution (XII).

The most important consideration here is the relative Independence of the size and the age of organizations. While size is related to those personnel behaviors (grievances, promotion requests, and strikes, work stoppages, etc.) which are hypothesized to be union inspired as part of the 
bargaining strategy and not necessarily a resultant of size per se, age, on the other hand, is independent of all personnel behaviors except for turnover. In general, nelther size nor age is appreciably related to personnel performance. Except for size being related to an increase in applicants (attractiveness or visibility), both size and age are independent of organizational functioning. The important implication of this observation along with the previous one is that personnel performance and organizational functioning do not covary substantially with the enduring and unalterable conditions of an organization (age and size), but vary with factors that can be manipulated such as the presence of recreation and savings-investment programs.

It is Interesting to note that while size of company is related to the presence of a number of incentive conditions and attributes, age of company is relatively independent of their presence.

In general, although both size and age are both considered to be important characteristics of organizations, size is by far the source of more varfance than age. Size is related to a number of variables in every category while age, outside of tenure, is independent of most all the other variables. The suggestion arises that size is a factor of far greater importance than age. 
Management Attributes

The management attributes investigated in the present study were quite homogeneous in that two factors accounted for essentially all of their variance. Three independent aspects of this category were disclosed. They are volume of management characteristics (I), management tenure (V), and management stock ownership (VI).

The data suggest that management tenure and experience are completely independent of other management characteristics such as age, education, pay level, and incldence of promotions. Because the management characteristics of age, education, pay level, and incidence of promotions are inextricably related to size, no unlque and clearcut relationships among them and other variables can be ascertained. However, it can be readily seen that management tenure and experience are consplcuously independent of other varlables, especially those involving personnel performance and organizational functioning. The implication seems to be that management tenure and experience in themselves are relatively unimportant as far as the personnel or organization behaviors measured in this study are concerned.

The only management attributes that have relationships with personnel performance and organization functioning are management stock ownership and submanagement tenure and in these Instances the complexity of the factors (VI and XII) concerned render any interpretation difficult. In one of 
these Instances stock ownership presumably reflecting interest in the organization was found to be inversely related to the incidence of machine down time, accidental damage to plant and equipment, pay requests, and customer complaints. These relationships were explained in the result section on the basis of stock owners protecting their own investments by cooperating toward certain organizational goals. In the other instance, Factor XII disclosed some rather low and ambiguous relationships among submanagement tenure and a few personnel performance and organizational function variables. By and large, the low magnitude and high complexity of the relationships between management attributes and other variables suggest that management variables offer not even a partial explanation of the characteristics and behaviors of organizations.

\section{Incentive Conditions, Benefits, and Programs}

One would not suspect that incentive conditions, benefits, and programs are so far removed from being undimensional in nature. That they are not undimensional is attested by their breaking up and scattering over nine different factors. For the most part, eight relatively Independent aspects of incentive conditions, benefits and programs present themselves. They are fringe benefits (I), discounts (III), financial incentives (IV), insurance benefits (VIII), improvement of working conditions $(X)$, recreation 
and savings-investment programs (XII), community pay scale (XIII), and pay increase (XIV).

Pay level tends to be related to worker characterlatics pertalning to skilI and education, and is independent of personnel performance and organizational functioning. quite the opposite holds true for recreation and savings-investment benefits which are essentially independent of worker characterlotics, but related to a number of personal performance (substandard production, and incidence of strikes, work stoppages, etc.) and organizational effectiveness (monetary civic support, management office holders, and increase in applicants) variables in the expected manner. Consequently, the importance of fringe benefits in the maintenance of performance is given some support. Also, as mentioned earlier, the notion of Likert (1959) and others that financial incentives have tended to be overemphasized in their facilitation of personnel performance was partially confirmed. As in Palmex's (1961) analysis, each one of the dimensions of incentive conditions, benefits, and programs is associated with different types of personnel behaviors.

In addition to the relationships mentioned above, discount was positively related to the incidence of lates; improvement of working conditions was positively related to the amount of substandard production and the incidence of strikes, work stoppages, etc.; and community pay rates 
positively related to the incidence of promotion requests. The author offers no explanation as to why discounts should be positiveiy related to the incidence of lates. The latter two groups of relationships were given consideration in the result section.

In summarizing, incentive conditions, benefits, and programs are multidimensional and the personnel behaviors with which they are associated are also multidimensional. Most important, however, is the observation that the linkages between these conditions and behaviors are unique.

\section{Worker Characteristios}

Worker characteristics scatter themselves over 12 factors. However, unton and ownership roles (I), employee age (II), family responsibility (III), skilled labor (IV), employee stockholders (VII), high school education (VIII), minority group membership (IX), Catholic affiliation (XIII), and hourly paid workers (XIV) were found to be relatively independent of one another.

Following the pattern of management attributes, employee tenure is independent of other worker characteristics, especially those involving skill and education. In both cases, tenure is unrelated to any identifiable organization attributes or conditions.

Employee tenure, age, sk111, and education are completely independent of personnel performance. Consequently, no support is given to Morse (1953) who found a negative 
relationshlp between skill level and voluntary turnover or to Van Zelst (1954) who presented evidence that accident rates decrease with age. Moreover, there was no evidence for higher turnover among males than females (Myers and Maclaurin, 1943) and for lower turnover among minority groups (March and Simon, 1958).

Although union membership was associated with grievances, strikes, work stoppages, etc., It was not related to any other personnel performance measures, especially those of an aversive nature lending no support to the view that unions serve to sublimate disoontent into union activity (Chapple and Sayles, 1961). Also, in agreement with Palmer (1961), various benefits (recreation, savings-investment, group Insurance, and discounts) were found not to be in the exclusive possession of unionized firms.

A striking feature of worker characteristics is that they seem to involve rather independent loyalties or commitrients to various organizations or social groups. Among these are loyalty toward the union, commitments to the family, loyalty to the firm, membership in the church, minority group membership, and responsibility to the firm through stock ownership. Moreover, each one of these loyalties or commitments seem to be related to unique personnel behaviors that seem to fulfill at least partially the requirements or demands of the group or organization concerned; unions are related to strikes, grievances, and 
promotion requests; family responsibility is associated with reporting to work on time; employee tenure is inversely related to tumover; stock ownership 18 inversely related to the incidence of machine down time, damage to plant and equipment, and pay requests; and membership in the Catholic church is inversely related to concern for promotion. AII of the above relationships provide support for March and Simon's (I958) multiple role concept.

\section{Personnel Performance}

Union behaviors (gxievances, promotion requests, and strikes, work stoppages, etc.) (I), lates (III), turnover (V), plant and equipment care (VI), substandard production (X), authority conflict (XI), output restriction (XII), and promotion requests (XIII) were found to be relatively independent aspects of personnel behavior. The present finding that productivity, job aversion, and theft are mutualiy independent behaviors is in agreement with Palmer (1961). However, Palmer (I96I) found job aversion behaviors to be rather unitary while in the present study aversive behariors split Into a number of independent components. For example, strikes, Iates, and turnover were found to be independent of each other. These are distinct ways of arolding the job and each seems to be related to unique conditions within the organization. Strikes are related to the presence of unions; turnover is associated with employee age and tenure; and tardiness covaries with family responsibility. 
Productivity loads slightly on three different factors and has no simple relationships with other variables. Theft, on the other hand, seems simply to be related to the presence of a retall sales force where opportunities for theft would seem to best present themselves.

A general implication about behaviors is that almost all performance measures are assoctated with some group loyalty or commitment. These relationships were detalled In the discussion of worker characteristics.

\section{Organizational Functioning}

The data suggest at least seven relatively autonomous aspects of organizational functioning. They are increase in applicants (I), economic growth (II), customer complaints (VI), workforce reduction (VII), management civic activity (XII), selectivity (XIII), and product development (XIV). A trend emerges here in that a number of these dimensions can be spoken of in terms of what group of organizational "participants" benefit or are effected one way or the other by the organization--the public (management civic support), the consumer (customer complaints), the employee (workforce reduction), the stockholder (economic growth of dividends, etc.) or the applicant (selectivity, percentage increase in applicants). An interesting implication arising here is that not only are each of these groups affected independently of one another but also the conditions assoclated with the 
functioning of these groups tend to be mutually independent and unique. In short, organizational policies designed to benefit one group (i.e. the stockholder) will not necessarily benefit other groups (i.e. the customer or the employee).

The interdependence of personnel performance and organizational functioning is noticeably absent in many respects. For example, one might expect personnel performance to covary with economic growth, and workforce reduction, but this is not supported by the present analysis. The few, complex, and invariably low relationships between performance and organization functioning were discussed previously in the results section, the most significant belng a positive relationship between substandard production, machine down time, and customer satisfaction. An inverse relationship between work output restriction and civic activity was also disclosed.

The Complexity of Organizational Attributes and Behavior The multitude of relationships disclosed in this investigation are complex and in many instances unique in that there is no theory or evidence with which to make comparisons. The discrepancies that do exist between the present study and other investigations can be partially explained by the fact that other investigations were conducted within companies, and the present study was conducted between 
companies. Even when company comparisons are made on the same or similar variables, discrepancies commonly occur (Brayfield and Crockett, 1955). Another difficulty is that the variables utilized in this study might be measuring something different than what the theorists are talking about. It is extremely difficult to quantify some of the constructs that are considered Important by various theorists (e.g. morale). Indeed, the theorists themselves are not certain what they mean by such concepts.

Some difficulty in interpretation was brought about by the fact that all of the factors were loaded by variables from at least two categories. The majority of the factors were of a three category complexity and in two instances varlables from all six categories saturated a factor. Probably the most significant aspect of this investigation is its demonstration of the complex relationships that can be expected to exist between various organizational attributes and behaviors. Typically, investigations have been concerned with a relatively few number of variables such that complex relationships were automatically ruled out. As more variables are taken into consideration, relationships among the original variables become altered and take on new significance. This is partially exemplified by comparing the results of the present investigation with those of Palmer's (1961). 


\section{SUMMARY AND CONCLUSIONS}

The purpose of this study was to explore some of the interrelationships among 84 variables pertaining to company and formal organization characteristics, management attributes, incentive conditions, worker characteristics, personnel performance, and organizational functions in a sample of manufacturing firms. The correlations among the 84 variables were factor analyzed and the factors rotated to a simple structure.

Fourteen dimensions of organizational attributes and behavior were isolated and interpreted. The factors were interpreted as follows: I. Size of Organization; II. Economic Growth; III. Tardiness vs. Family Responsibility; IV. Pay-SkIII Level; V. Personnel Tenure; VI. Ownership and Concern for Organizational Interests; VII. Work-force Reduction and Job Mechanization; VIII. Technical Personnel and Controls rs. Protection Against Human Liabilities; IX. Minority Group Composition; $x$. Improvement of Working Conditions; XI. Retail Sales Personnel and Authority Conflict Behaviors; XII. Community and Employee Support va. Work Output Restriction; XIII. Personnel Selectivity; XIV. AIlocations to Labor vs. Product Development.

The size of the firm was found to be a far greater source of varlance than was the age of the firm. However, 
neither size nor age was appreciably related to measures of personnel performance and organizational functioning. Personnel performance and organizational functioning varied with factors that could be controlled (e.g. recreation and savings-investment programs) rather than with the enduring and unalterable conditions of an organization such as size and age.

Management tenure and experience were completely independent of other management characteristics such as age, education, pay 1evel, and incidence of promotions. Most important, management tenure and experience were conspicuously independent of other variables, especially those involving personnel performance and organization functioning.

In regard to incentives, pay level tended to be related to worker characteristics pertaining to skill and education and was independent of personnel performance and organizational functioning. Quite the opposite held true for recreation and savings-investment programs which were essentially independent of worker characteristics, but related to a number of personnel performance and organizational functioning variables.

Following the pattern of management attributes, employee tenure was independent of other worker characteristics, especially those involving skill and education. Moreover, all the worker characteristics mentioned above were completely independent of personnel performance measures. A striking 
feature of worker characteristics was that they seemed to involve rather independent loyalties or commitments to various organizations or social groups. Furthermore, each one of these loyalties or commitments tended to be related to unique personnel behaviors.

Productivity, job aversion, and theft were mutually independent behaviors. However, job aversion behaviors split up into a number of independent components, each one being associated with unlque conditions within the organization. Productivity was found to have no simple relationships with other variables.

A number of independent dimensions of organization functioning could be interpreted in terms of what group of organizational "participants" benefit or are effected one way or another by the organization. The interdependence of personnel performance and organization functioning was noticeably absent in many respects.

Probably the most Bignificant aspect of this investigation is its demonstration of the complex relationships that can be expected to exist between various organizational attributes and behaviors. As more variables are taken into consideration, relationships among the original variables become altered and take on new significance. 


\section{BIBLIOGRAPHY}

Argyris, C. Understanding organizational behavior. Homewood, Ill.: Dorsey Prass, Ine., 1960.

Bass, B. M. Ultimate criteria of organizational worth. Personnel Paychol., 1952, 5, 57-173.

Bass, B. M. Leadership psychology and organizational behavior. New York: Harper, 1960.

Bass, B. M. Experimenting with simulated manufacturing organizations. Tech. Rep. 27, Contract N7 ONR 35609, Louisiana State Univer., Baton Rouge, 1961.

Bavelas, A. Communication patterns in task oriented groups. I. gcoust. soe. Amer., 1950, 22, 725-730.

Baumgartel, H., \& Sobol, R. Background and organizational factors in absenteeism. Personnel Psychol., 1959, 12, $431-443$.

Blau, P. M. Formal organization: dimensions of analysis. Amer. I. Soc1ol-, 1957, 63, 58-69.

Bowen, H. R. The business enterprise as a subject for research. Social Sclence Research Counc1l, pamphlet No. $11,1957$.

Brayfield, A. H., \& Crockett, W. H. Enployee attitudes and employee performance. Psychol. Bull., 1955, 52, 396424.

Cartwright, D. The potential contribution of graph theory to organizational theory. In Haire, M. (Ed.) Modern organizational theory. New York: Wiley, 1959.

Cartwright, D., \& Zander, A. F. (Eds.) Group dynamics: research and theory. Evanston: Row, Peterson, 1960.

Castle, P. F. Accidents, absence, and withdrawel from the work situation. Hum. Relat., 1956, 2, 223-233.

Chapple, E. D., \& Sayles, I. R. The measure of management. New York: Macmillan, 1961. 
Coch, L., \& French, J. R. Overcoming resistance to change. Hum. Relat., 1948, I, 512-532.

Cyert, R. M., \& March, J. G. A behavior theors of organizationai objectives. In Haire, M. (Ed.) Modern organizational theory. New York: Wiley, 1959.

Dent, J. K. Organizational correlates of the goals of business management. Personnel Psychol., 1959, 12, 365393.

Ghisell1, E. E., \& Brown, C. W. Personnel and Industrial psychology. New York: McGraw-Hill, 1948.

Haire, M. (Ed.) Modern organizational theory. New York: Wiley, 1959.

Herzberg, F., Mausner, B., \& Snyderman, Barbara. The motivation to work. New York: Wiley, 1959.

Hoggatt, A. C. An experimental business game. Behavioral Sci., 1959, 4, 192-203.

Hotelling, $H$. Analysis of a complex of statistical variables into prineiple components. I. educ. Psychol., 1933, 24, 417-441, 498-520.

Kaiser, H. F. The varimax criterion for analytic rotation factor analysis. Psychometrika, 1958, 23, 187-200.

Katz, D., Maccoby, N., \& Morse, N. C. Productivity supervision and moral in an office situation. Inst. Soc. Reg., Univer. of Mich., Ann Arbor, 1951.

Kennedy, J. L. Gaming theory and its relation to industrial psychology. Presented at the 67th Ann. Conv. Amer. Psychol. Assoc., Cincinnat1, OhIo, 1959.

Kerr, W. Labor turnover and its correlates. I. appl. Psychol., 1.947, 31, 366-371.

Leavitt, H. J. Some effects of certain communication patterns on group performance. I. abp. soc. Psychol., 1951, 46, 38-50.

Iikert, R. Measuring organizational performance. Harvard Bus. Rev., 1958, 26, 41-5\%.

Iikert, R. A motivational approach to a modified theory of organization and management. In Haire, $M_{0}$ (Ed.) Modern organizational theory. New York: Wiley, 1959. 
March, J. G., E Simon, H. A. Organizations. New York: Wiley, $1950^{\circ}$.

Marriot, R. Socio-psychological factors in productivity. Occup. Psychol., 1951, 25, 15-24.

Marschak, J. Efficlent and viable organizational forms. In Haire, M. (Ed.) Modern organizational theory. Now York: Wiley, 1959.

McGregor, D. The human side of enterprise. New York: Me Graw-Hi11, 1960 .

Morse, N. C. Satisfactions in the white-collar job. Survey Research Center, Univer. of Michigan, 1953.

Mulder, M. Communication structure, decision structure and group performance. Sociometry, 1960, 23, 1-14.

Myers, C. A., E Maclaurin, W. R. The movement of factory workers. New York, 1943.

Palmer, G. J., Jr. Incentive conditions and behavior in 188 industrial manufacturing organizations. Tech. Rep. 3, Project NR 170-478, Contract Nonr 475(08), Tulane Univer., 1961.

Rapaport, A. A logical task as a research tool in organization theory. In Haire, M. (Ed.) Modern Orsanizational theory. New Iork: Wiley, 1959.

Revans, R. W. Human relations, management and size. In Hugh-Jones, E. M. (Ed.) Human relations and modern mapagement. Amsterdam, Netherlands: North Holland, 1958.

Rubenstein, A. H., E Haberstroh, C. J. (Eds.) Some theories of organization. Homewood, Ill.: IrwinDorsey, 1960.

Shartle, C. I. Executive performance and leadership. Englewood Cliffs, N. J.: Prentice-HaII, 1956.

Shaw, M. E. A comparison of two types of leadership in various communication nets. I. abnorm. soc. Psrahol., $1955,50,127-134$.

Tannenbaum, R., Wechsler, I. R., E Massarik, F. Leadership and organization. New York: MeGraw-H111, $1 \overline{961 .}$ 
Thorndike, R. L. Personnel selection. New York: Wiley, 1949.

Urwick, I. F. Elements of administration. New York: Harper, $1944^{\circ}$

Van Zelst, R. H. The effect of age and experience upon accldent rate. I. appl. Psrchol., 1954, 38, 313-317.

Viteles, M. S. Motivation and morale in industry. New York: Norton, 1953.

Whyte, W. F. Man and organization. Homewood, III.: Richard D. Irwin, Inc., 1959.

Worthy, J. C. Factors influencing employee morale. Harvard Bus. Rev., 1950, 28, 61-73. 
APPENDIX A

Item Distributions

56

PLEASE NOTE: Appendices contain several pages with extremely fine type. Filmed as received. UNIVERSITY MICROFILMS, INC. 
SURVEY OF MANUFACTURERS

Company ard Formal OrganizatIon Gharactoristics

1. How old is your firm?

1. $0-5$ years

2. $6-10$

3. $11-25$

4. $16-25$

5. $26-40$

6. 41-60

7. $61-100$

8. Ovor 100 yearg old

* N. A.

$\%$
5.6
9.4
17.5
13.2
19.7
19.2
11.5
3.0
.9

2. How many omployeos aro currontly in your firm?

$\begin{array}{lr}\text { 1. } 1-2 & 2.1 \\ \text { 2. } 3-5 & 9.0 \\ \text { 3. } 6-1.0 & 17.1 \\ \text { 4. } 11-25 & 20.9 \\ \text { 5. } 26-50 & 17.5 \\ \text { 6. } 51-150 & 16.2 \\ \text { 7. } 151-300 & 6.8 \\ \text { 8. 301-1000 } & 7.3 \\ \text { 9. Over 1000 } & 2.1 \\ \text { N. A. } & .9\end{array}$

3. Approximately what is the popilintion of the community in which your firm is located?

1. 0-5000 Inhabitant:

2. $5,001-15,000$

3. $15,001-30,000 \quad 6.4$

4. $30,001-50,000 \quad 9.8$

5. $50,001-100,000 \quad 13.2$

6. $100,001-500,00015.0$

7. Over 500,000 21.8

- N. A. 2.5

4. How is production quality controlled?

1. Judgmont of an Inspector

2. Mechanical, electrical, statist1cal, or othor methods N. A. 3.0
5. Does your firm PRLMARLYY manufacture ono or a fow standard producta for inventory only or produce various products based on custorner ordors?

1. Produce for Inventory

2. Produce for orders. N. $A$.

6. How many retail sales personnol selling directly to consumers do you havo?

$\begin{array}{lr}\text { 1. None } & 44.9 \\ \text { 2. } 1-3 & 23.5 \\ \text { 3. } 4-6 & 10.3 \\ \text { 4. } 7-1.5 & 3.4 \\ \text { 5. } 16-30 & .9 \\ \text { 6. Over } 30 & 1.7 \\ \text { 7. No information } & 15.3\end{array}$

7. What is the territory that Bist describus tho area over which your products aro distributad? (Chock ONE only)

$\begin{array}{lr} & \% \\ \text { 1. Local } & 26.9 \\ \text { 2. Stato-wide } & 7.3 \\ \text { 3. Regional (homo } & \\ \text { stato and adja- } & \\ \text { cont states } & 23.1 \\ \text { 4. National } & 28.6 \\ \text { 5. Intornational } & 13.2 \\ \text { N. A. } & .8\end{array}$

8. How many minagement person-11. nel (supervisors and abovo) do you have?

$\begin{array}{lr} & \text { \% } \\ \text { 1. } 1 & 12.8 \\ \text { 2. } 2 & 20.5 \\ \text { 3. } 3-4 & 24.4 \\ \text { 4. } 5-10 & 20.9 \\ \text { 5. } 11-20 & 7.7 \\ \text { 6. } 21-50 & 8.1 \\ \text { 7. 51-1.00 } & 2.1 \\ \text { 8. Over } 100 & 1.7 \\ \text { N. } \text { A. } & 1.7\end{array}$

9. In plant, on tho evorago, how many employeos por foreman aro there? (bixproses 28 total plant omployees/numbor plant foremon.) of command from for to prosident or top executive of your firm, how many supervisory or managoment lovols aro thare? (Includo in your count the lovels of prosident and foreman.)

0. All supervision performed by man2gor-ownor 19.2

1. Foroman and top oxecutive only 26.1

2. $3 \quad 18.4$

3. $4 \quad 13.7$

4. 5

5. $6 \quad 5.1$

6. 7 2.1

7. $8 \quad 1.3$

8. $9 \quad 1.7$

9. No information 4.3

How many roctanglos (soparate departmonts or divigions, e.g. plant ong1neoring, industrial rolations, office of controller, office of prosident, otc.) are thero on your firm's organization chart, how many rectanglos would there bo if you drow one up?)

(HII continued on noxt pago)

* No Anowor 
11. (Continued)

0 . No information 27.4

1. 1

2. 2

3. 3

4. $4-5$

5. $6-10$

6. 11-15

7. $16-20$

8. 21-30

9. Over 30

12. At present, about what percentage of your firm's total employed are involved in personnel management, quality control, purchasing, production control, maintenanco, product and process design, controllorship, market research, and time and motion study? (Total all people that work in these aroas and express as a percentage of total omployed.)

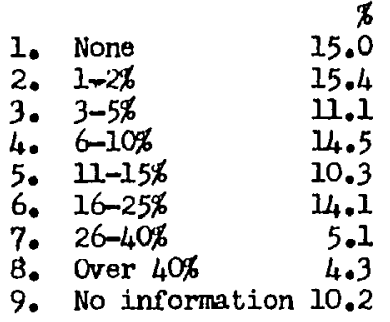

13. How many technical or professional people with primary job responsibilities in research and development do you have?

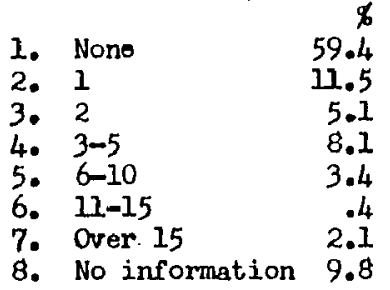

\section{Management Attributos}

14. In general, how is your management personnol paid?

1. Owner's share of profits 13.2

2. Paid on a salary basis 50.0

3. Straignt salary plus sharo of profits 29.9

4. Salary plus commission 4.7

5. Salary plus comnission and share of profits $\quad 1.7$ N. A. $\quad .4$

15. At present, what is the averago tenuro for managoment (supervisors and above) in your firm?

$\begin{array}{llr} & & \% \\ \text { 1. } & 1-3 \text { years } & 6.0 \\ 2 . & 4-6 \text { years } & 11.5 \\ \text { 3. } 7-9 \text { years } & 12.0 \\ \text { 4. } 10-12 \text { years } & 17.5 \\ \text { 5. } 13-16 \text { years } & 9.0 \\ \text { 6. Over } 16 \text { years } & 29.9 \\ \text { 7. No information } 13.6\end{array}$

16. What is the average length of time your present management persounel has spent at sub-management levels (below supervisory levol)? (Include time spent at sub-management lovels in other firms as well as within your own firm.)

1. $0-2$ years $\quad 12.8$

2. 3-5 years 12.4

3. 6-8 years 24.4

4. $9-12$ years 13.2

5. $13-16$ years 6.8

6. 17-20 yoars 1.7

7. Over 20 years 3.4

8. No information 25.2
17. What is the average amount of time that your present management (supervisors and above) has had in managerial experience at supervisory lovols or above? (Include experience gained in othor firms as woll as withy your own firm.)

$\begin{array}{llr} & & q \\ 1 . & 0-5 \text { years } & 14.5 \\ 2 . & 6-8 \text { years } & 13.2 \\ 3 . & 9-12 \text { yoars } & 19.2 \\ \text { 4. } 13-15 \text { years } & 11.1 \\ \text { 5. } 16-20 \text { yoars } & 14.1 \\ \text { 6. Ovor 20 years } & 11.5 \\ 7 . & \text { No information } 16.2\end{array}$

18. What is the approximate difference between the pay for general manager and averago pay at the level of supervisor?

1. $\$ 1-\$ 500 \quad 11.5$

2. $\$ 501-\$ 2,000 \quad 10.7$

3. $\$ 2,001-\$ 4,000 \quad 14.5$

4. $\$ 4,001-\$ 8,000 \quad 18.4$

5. $\$ 8,001-\$ 10,0007.7$

6. $\$ 10,001-\$ 20,0006.8$

7. Over $\$ 20,0002.6$

8. Have no supervi$\begin{array}{lr}\text { sors } & 21.8 \\ \text { N. A. } & 6.0\end{array}$

19. How many of your managemont personnel (supervisors and above) are company stockholders?

0 . No information 9.0

1. Company has no stock

25.6

2. Nono 17.9

3. $1 \quad 12.8$

4. $2 \quad 12.4$

5. $3 \quad 6.8$

6. 4-5 5.1

7. $6-10 \quad 3.0$

8. 11-20 2.1

9. Over 20 5.1 
20. How mary of your prosent managemont personnel (supervisiors and abovo) have a collego dogreo?

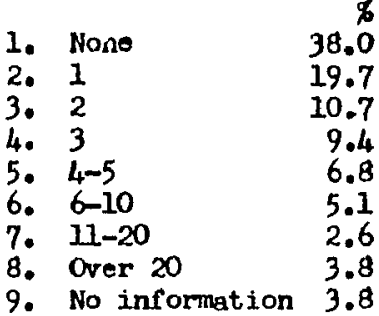

21. How many of your present managoment porsonnel (supervisors and abovo) earn $\$ 15,000$ or more dollars por yoar?

$\begin{array}{lr} & \% \\ \text { 1. Nono } & 54.7 \\ 2.1 & 14.5 \\ 3.2 & 11.1 \\ \text { 4. } 3 & 6.0 \\ \text { 5. } 4-5 & 3.0 \\ 6.6-10 & 2.6 \\ 7.21-20 & 1.3 \\ \text { 8. Over 20 } & 1.3 \\ \text { 9. No information } & 5.5\end{array}$

22. How many of your present management personnel (supervisors and above) aro 50 years of age or older?

$\begin{array}{lr}\text { 1. None } & 34.2 \\ \text { 2. } 1 & 24.8 \\ \text { 3. } 2 & 15.8 \\ \text { 4. } 3 & 9.8 \\ \text { 5. 4-5 } & 6.0 \\ 6.6-10 & 2.1 \\ 7 . \text { 11-20 } & 2.6 \\ \text { 8. Ovor 20 } & 1.3 \\ \text { 9. No information } & 3.4\end{array}$

23. In the 6 month period (Jan. 1, 1961 through June 30, 1961), approximately how many pre-8ched-26. uled (formal) conunittee meotings were held in which 2 or more of your management personnol participated?

\begin{tabular}{|c|c|c|c|c|}
\hline $\begin{array}{l}0 . \\
1 . \\
2 . \\
3 . \\
4 . \\
5 .\end{array}$ & $\begin{array}{l}\text { No information } \\
\text { Have no com- } \\
\text { mittoos } \\
1 \\
2 \\
3-4 \\
5-6 \\
7-10\end{array}$ & $\begin{array}{r}11.1 \\
49.6 \\
2.1 \\
3.4 \\
3.4 \\
6.8 \\
2.6\end{array}$ & $\begin{array}{l}1 . \\
2 . \\
3 . \\
4 . \\
5 . \\
6 .\end{array}$ & $\begin{array}{l}0-10 \% \\
11-20 \% \\
21-35 \% \\
36-50 \% \\
51-65 \% \\
66-30 \% \\
\text { Orer } 80 \% \\
\text { N. A. }\end{array}$ \\
\hline
\end{tabular}

27. When you compare jubs in your company with comparablo Jobs in other compantes in your comminity, how in general do your pay rates compare? (supervisors wero promoted to these positions from lower positions in your firm? \%

0 . No information 7.7

1. None 32.9

2. 1 11.1

3. $2 \quad 11.1$

4. 3-4 14.1

5. $5-6$

6. $7-10$

7. $11-25$

6.8

8. $26-40$

9. Over 40

5.6

5.6

1.7

3.4

Incentive Conditions, Benefits. and Programs

25. Not counting managomont and afice workers, about, what percontago of your firm's presont plant workers earn $\$ 400$ or more per month?

$\begin{array}{lr}\text { 1. } 0-10 \% & 32.9 \\ \text { 2. } 11-20 \% & 9.4 \\ \text { 3. } 21-35 \% & 8.1 \\ \text { 4. } 36-50 \% & 7.3 \\ \text { 5. } 51-65 \% & 5.6 \\ \text { 6. 66-80\% } & 9.8 \\ \text { 7. Over 80\% } & 21.4 \\ \text {. N. A. } & 5.5\end{array}$

29. At the present time, what is the pay differential between the lowost and highest job classification for hourly-paid line production workers?

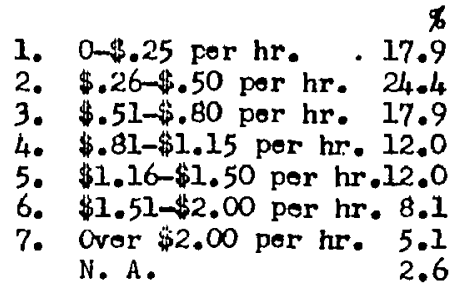


30. Do you have a pension prom gram?

1. yes $\quad 39.5$

31. Does your company offor group insurance, such as life, hospltalization, and the like?

$\begin{array}{lr}\text { 1. yes } & 80.8 \\ \text { 2. no } & 18.8 \\ \text { N. A. } & .4\end{array}$

32. Do you have a company sponsored savings or investmont plan?
1. yeg
2. no
15.4
84.6

33. Do you pay salaried employees who are absent due to non-occupational infury or sickness?

$\begin{array}{lr}\text { 1. yes } & 79.9 \\ \text { 2. no } & 17.1 \\ \text { N. A. } & 2.9\end{array}$

34. Approximately what discount do you allow omployees on purchases of compary producta?

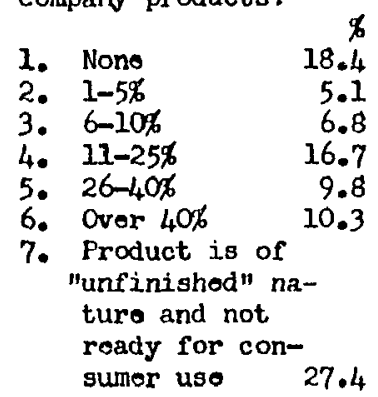

35. On the averago over the past 5 years or since ostablishment if your firm is less than 5 years.old, what have been the costs of fringe benefits ex- presaed as a percontago of the total payroll?

1. $0-2 \frac{1}{3}$ of total payroll 22.2

2. $2 \frac{1}{2}-5 \% \quad 26.7$

3. 5-10\% 14.1

4. $11-1.5 \% \quad 10.3$

5. Ovor $15 \% \quad 16.7$

6. No information 20.1

36. About what percentago of your firm's total parsonnel recelved pay in-39. Not counting management, creasises during the your 1960 ?

1. None

2. $1-25 \%$

3. $26-50 \%$

4. $51-70 \%$

5. 71-80\%

6. $81-90 \%$

7. $91-100 \%$

$$
\begin{array}{r}
76 \\
9.8 \\
18.8 \\
9.4 \\
6.4 \\
3.0 \\
7.3 \\
42.3
\end{array}
$$

8. No information 3.0

37. About what porcentage of youx total personnel received promotions during the yoars 1959 and 1960 ?

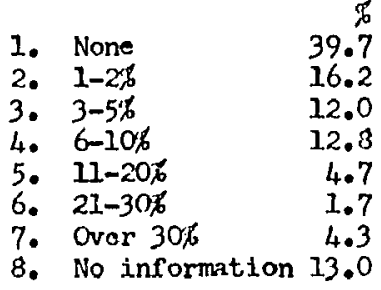

38. For the years 1956 through 1960, or since astablish-41. mant of your firm if J.sss than 5 years old, how mach money has been invested in the improvement of working conditions ( 0.8 . illumination, temperature. humidity, etc.) and the improvoment of convenience or recreational facilities (e.g. rest, recreation, and dining rooms, otc.) expressod as a percentage of profits mado during this period?

$\begin{array}{llr}\text { 1. } & & \% \\ 2.2 \% & 25.6 \\ 3-5 \% & 13.7 \\ \text { 3. } 6-10 \% & 11.5 \\ \text { 5. } 16-20 \% & 6.0 \\ 6 . & 3.0 \\ \text { 7. Nor } 20 \% & 13.7 \\ & \text { No information } 26.5\end{array}$

Worker Charncteristics 
42. Not counting management, about what percentage of your firm's employees aro Catholic in religious affiliation?

$\begin{array}{lr}\text { 1. } 0-5 \% & 30.8 \\ 2.6-10 \% & 4.3 \\ 3 . \quad 11-15 \% & 4.7 \\ \text { 4. } 16-20 \% & 5.6 \\ \text { 5. } 21-30 \% & 4.3 \\ 6.31-40 \% & 6.4 \\ \text { 7. } 41-60 \% & 8.5 \\ \text { 8. Over 60\% } & 6.0 \\ \text { 9. No information } & 29.5\end{array}$

43. Approxinatoly what percentage of your present workforce is composed of machine operators?

$\begin{array}{lr} & \\ \text { 1. } 0-5 \% & 24.8 \\ \text { 2. } 6-10 \% & 9.0 \\ \text { 3. } 11-20 \% & 9.0 \\ \text { 4. } 21-30 \% & 9.4 \\ \text { 5. 31-50\% } & 15.4 \\ \text { 6. Over 50\% } & 29.1 \\ \text { N. A. } & 3.4\end{array}$

44. Not counting managemont, about what percontago of your presont working force is composed of Anerican-born white

Christions?

$\begin{array}{lr} & \% \\ \text { 1. } 0-40 \% & 10.3 \\ \text { 2. } 41-65 \% & 5.1 \\ 3.66-75 \% & 4.3 \\ \text { 4. } 76-80 \% & 1.3 \\ \text { 5. } 81-85 \% & 3.4 \\ \text { 6. } 86-90 \% & 4.3 \\ \text { 7. 91-95\% } & 7.3 \\ \text { 8. 96-100\% } & 51.7 \\ \text { 9. No information } 12.4\end{array}$

45. Approximately what percentago of your present ouployees are union menisers?

$\begin{array}{lr}\text { 1. Have no union } & 61.1 \\ \text { 2. Los than } 20 \overrightarrow{6} & 2.1 \\ \text { 3. } 21-40 \% & 2.6 \\ \text { 4. } 41-606 & 5.1 \\ \text { - } & \end{array}$

$\begin{array}{lr}\text { 5. 61-80\% } & 8.1 \\ \text { 6. } 81-90 \% & 6.4 \\ \text { 7. Over } 90 \% & 13.2 \\ \text { N. A. } & 1.3\end{array}$

46. Not counting manzgoment, what porcentage of your firm's present amployoss have comploted high school? \%

1. None

2. $1-10 \%$

3. $11-20 \%$

4. 21-35\%

5. 36-60\%

6. Over $60 \%$

1.7

5.6

3.8

7.3

7. No information 11.9

47. Not counting managomont, what porcentage of your firm's prezent omployoes have beon with your firm 5 or more years?
1. $0-20 \%$
2. 2].-40\%
3. $41-60 \%$
4. $61-80 \% 6$
5. $81-100 x$
No information 1.7

48. Not counting managoment, about what percontage of your firm's presont employes are male?

1. $0-40 \%$

2. $41-70 \%$

3. 71-80\%

4. $81-856$

5. $86-906$

6. $91-956$

7. $96-1006$

N. $\wedge$.
12.8
13.7
9.8
5.6
9.8
12.8
35.0
.4

49. Approximately what percentige of your firm's presont enployeses aro married and have two or moro children?

1. $0-50 \%$

$\%$
24.8

2. $51-756$

3. 76-85\%

4. $86-90 \%$
22.2

13.2

10.3
5. 91-95\%

6. 96-100\%

7.3

7. No information $\mathbf{1 5 . 4}$

50. At present, approximately what porcentage of your plant workers aro sktlled laborers? (1.0. craftsmon and highly skillod manual workers who have completed appronticoships or extensive training programs)

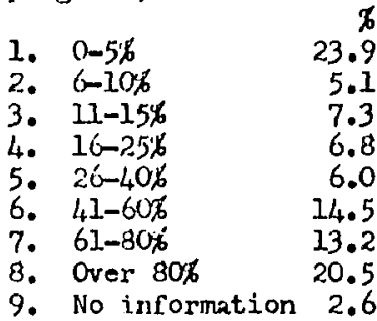

51. Not counting managemunt, approximstely what forcentege of your present employoes aro 40 years of age or over?

1. $\quad 0-20 \%$

2. $21-40 \%$

3. 41-50\%

4. $51-60 \%$

5. 61-70\%

6. $71-80 \%$

7. Over 80\%

$$
\begin{array}{r}
4 \\
18.4 \\
17.9 \\
22.6 \\
14.1
\end{array}
$$

52. About what percentage of your total employed aro Nugroos?

$\begin{array}{lr}\text { 1. nono } & . \% \\ \text { 2. } 1-2 \% & 56.0 \\ \text { 3. } 3-5 \% & 12.0 \\ \text { 4. } 6-10 \% & 5.1 \\ \text { 5. } 11-20 \% & 7.3 \\ \text { 6. } 21-40 \% & 3.0 \\ \text { 7. 41-60\% } & 1.3 \\ \text { 2. Over } 60 \% & 3.0 \\ \text { 9. No information } & 2.6 \\ & 9.8\end{array}$


Porsonnel Porformance

53. On tha averago for 1960 , how much machine down time due to breakulowns, absences, powor failures, 56. dolay in stock and the like was thors, expressed $2 s$ a porcontago of total machino runing time?

$\begin{array}{lr}\text { 1. None } & \% \\ \text { 2. } 1 \% \text { or under } & 14.5 \\ 3 . & 29.9 \\ \text { 4. } 2-3 \% & 9.4 \\ \text { 5. 3-4\% } & 5.6 \\ \text { 6. 4-10\% } & 5.6 \\ \text { 7. } 10-20 \% & 6.0 \\ \text { 8. Over 20\% } & 1.7 \\ \text { 9. No information } 26.1\end{array}$

54. For the years 1956 through 1960, what has been the extent of ACCLDBNTAL damago to equipmont and plant facilitios oxpressed in dollars?

1. Furn is loss 3.4 than 5 years old

2. $\$ 0-\$ 500$

39.7

3. $\$ 501-\$ 1,000 \quad 12.8$

4. $\$ 1,001-\$ 2,000 \quad 5.1$

5. $\$ 2,001-\$ 5,000 \quad 9.8$

6. $\$ 5,001-\$ 15,000 \quad 6.8$

7. $\$ 15,001-\$ 40,0001.3$

8. Ovor $\$ 40,000$ 20.9

55. For the years 1951 through 1960, what has beon the number of strikes, work stoppages, slow downs, walkouts, and the like in your firm?

1. Firm is less than 10 years old

2. Nono

3. 1

4. $2-3$ $\not$
10.7

76.1

5.6

3.0

$\begin{array}{lr}\text { 5. } 4-5 & 2.1 \\ \text { 6. 6-8 } & .0 \\ \text { 7. Over } 8 & .4 \\ \text { N. A. } & 2.1\end{array}$

In 1960 , about what percentago of your overall production did you reject as boing bolow your accoptable standards?

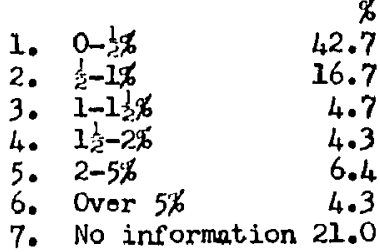

57. On an averago day in 1960 , approximately what was the averago number of employeos absent per day?

$\begin{array}{lr}\text { 1. None } & \% \\ \text { 2. } 1-2 & 50.4 \\ \text { 3. } 3-4 & 23.9 \\ \text { 4. } 5-8 & 4.7 \\ \text { 5. } 9-15 & 5.1 \\ 6.16-30 & 3.4 \\ \text { 7. Ovor 30 } & 1.7 \\ \text { 8. No information } & 1.3 \\ \end{array}$

58. During 1960, from what porcuntage of your employeos did you roceive grievances or complainto?

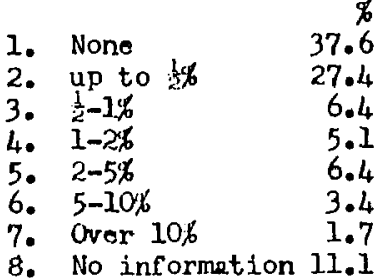

59. For the years 1956 through 1960 , what has boen your approximate yearly omployso turnover?

\begin{tabular}{lr} 
& $\%$ \\
0. Nono & 22.4 \\
1. 1\% of total & .5 \\
2. workforce & $29.5 \%$ \\
3. $4-5 \%$ & 18.8 \\
4. $6-8 \%$ & 9.0 \\
5. 9-12\% & 6.1 \\
6. 13-25\% & 5.6 \\
7. Over 25\% & 6.8 \\
8. No information & 5.1 \\
\hline
\end{tabular}

60. On an everage day in 1960 , about what percentage of your employoes roturned to work late after the lunch poriod?

\begin{tabular}{|c|c|}
\hline $\begin{array}{l}\text { Nono } \\
\text { Up to } \\
\frac{1}{2} \% \\
\frac{1}{2}-1 \% \\
1-1 \% \\
112-2 \% \\
2-4 \% \\
5-8 \% \\
\text { Over } 8 \%\end{array}$ & $\begin{array}{r}38.0 \\
27.8 \\
7.7\end{array}$ \\
\hline
\end{tabular}

61. About how many instances of theft of company property by employoos did you receivo in the years 1959 and 1960 ?

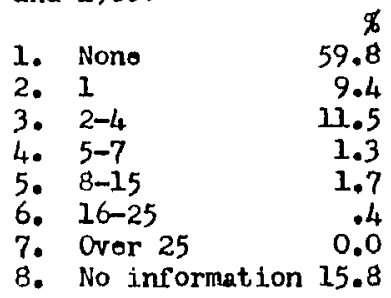

62. For the years 1959 and 1960 how many incidents have there been involving a SLiKLOUS conflict botween superior and subordinato (e.g. physical 233ault, vorbal threat, and tho like) which rosultad in adninistrative zction (o.g. dischargo, roprimand, otc)?

(\#62 continued on noxt pago) 
62. (continuod)

$\begin{array}{lr} & \\ \text { 1. None } & 71.8 \\ \text { 2. } 1 & 11.5 \\ 3.2 & 5.1 \\ \text { 4. } 3 & 2.1 \\ \text { 5. 4-5 } & .4 \\ 6 . \text { 6-10 } & .0 \\ 7 . \text { Ovor 10 } & .0 \\ \text { 8. No information } & 9.0\end{array}$

63. For the yoars 1959 and 1960 how many of your employees havo boon involved in an accidont roquiring first aid or hospitalization?

$\begin{array}{lr} & \% \\ \text { 1. None } & 20.1 \\ 2 . & 1 \\ \text { 3. } 2 & 12.4 \\ \text { 4. } 3 & 9.0 \\ \text { 5. } 4-5 & 10.3 \\ \text { 6. } 6-7 & 13.2 \\ 7 . \text { 8-15 } & 6.0 \\ \text { 8. Ovor 15 } & 5.1 \\ \text { 9. No information } & 15.4 \\ \end{array}$

64. For the years 1959 and 1960 how many of your mployeos woro discharged because of incompetonce, dishonosty, nogligence or other reasons that mide them unfit for ermloyment?

$\begin{array}{lr}\text { 1. Nono } & 39.7 \\ 2.1 & 15.0 \\ 3.2 & 17.1 \\ \text { 4. } 3 & 9.0 \\ 5.4-5 & 7.3 \\ 6.6-7 & 4.7 \\ 7.8-15 & 3.0 \\ 8 . \text { Over 15 } & 3.4 \\ 9 . \text { No information } & 6.8\end{array}$

65. On an averago day in 1960 , about what porcentago of your employoos rom ported late at the start of the workday?

$\begin{array}{lr} & \% \\ 0 . \text { None } & 26.5 \\ 1.0-1 \% & 38.0 \\ 2 . & 8.5\end{array}$

$\begin{array}{ll}\text { 3. } 1-1 \frac{1}{2} \% & 2.6 \\ \text { 4. } 1 \frac{1}{2}-2 \% & 4.3 \\ \text { 5. } 2-3 \% & 2.1 \\ 6.3-5 \% & 2.1 \\ \text { 7. 5-8\% } & 2.1 \\ \text { 8. Ovor } 8 \% & 4.7 \\ \text { 9. No informetion } 9.0\end{array}$

66. On the 2vorage for the yoars 1959 and 1960, what percentaga of your omployeos subraittod requests for promotions?

o. Nono

$\%$

1. Up to $2 \%$

42.3

2. $2-3 \%$

3. $4-5 \%$

4. $6-10 \%$

5. $11-20 \%$

6. 2l-40\%

7. Over $40 \%$

8.1

4.7

3.8

.9

.9

8. No informution 16.2

67. On the averiage for the years 1959 and 1960, what percentage of your einploycos submitted roquest for 70. pay raises?

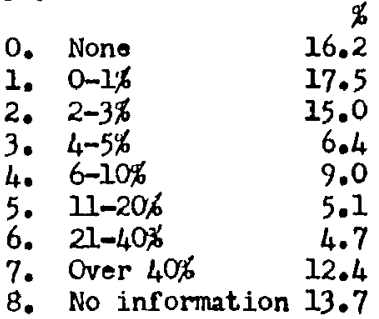

68. For the years 1956 through 1960, how many employees wero known to have been porsons with montal illnoss, criminal offenses, or addictions $(0 . \mathrm{g}$. alcohol or drugs? (Count persons who have left the firm in this poriod and also thoso who aro now omployed.)

1. None
2. 1
3. 2
4. 3$$
\begin{array}{r}
51.3 \\
11.5 \\
9.4 \\
3.0
\end{array}
$$

5. 4-5

6. 6-7

7. $8-15$

8. Over 15

4.7

9. No information 7.7

\section{Organization Eunction}

69. For the years 1956 through 1960, how many jobs were oliminated by the introduction of labor-saving dovices?

0 . Firm is loss $\mathrm{H}_{\text {.I }}$ than 5 yoars old

1. None

2. 1

3. 2

4. $3-5$

5. $6-10$

6. 11-15

7. $16-30$

8. Over 30

9. No information 6.8

For the yoars 1951 through 1960 or since extablishmont if your firm is loos than 10 yoars old, how many complotely NEW prom ducts have boon put on the mirkot? Do not count simple alterations of provious lines; count only producto now to your firm.

$\begin{array}{lr} & \% \\ \text { 1. } 0 & 31.2 \\ 2.1 & 6.4 \\ \text { 3. } 2 & 12.0 \\ \text { 4. } 3-4 & 15.4 \\ \text { 5. } 5-6 & 6.8 \\ 6.7-10 . & 5.6 \\ 7.11-15 & 3.0 \\ \text { 8. 16-25 } & .4 \\ \text { 9. Gvor } 25 & 7.3 \\ \text { N. } \Lambda . & 12.0\end{array}$

For the yours 1956 through 1960 , how much was contributed to the support of various conuminity and civic affairs including charity? (Express as a porcent of

(\#71 continued on next page) 
71. (Continued) profit mado in this poriod.)

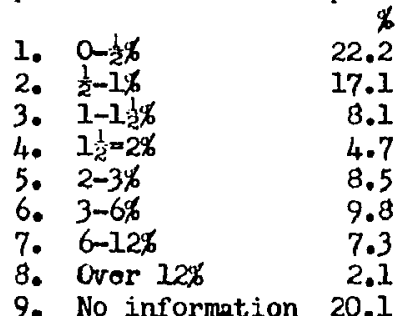

72. For the years 1956 through 1960 , on the avorago, approximatoly what has your firm's soloction ratio boon? (If your firm is less than 5 yoars old, use ratio since ostablishmont.)

NOTE: Seloction ratio equals No. selected from anong total applicants/ total No. of applicants

\begin{tabular}{|c|}
\hline $\begin{array}{l}.0-.10 \\
.11-.20 \\
.21-.30 \\
.31-.40 \\
.41-.50 \\
.51-.65 \\
.66-.80 \\
.81-1.00 \\
\text { No information }\end{array}$ \\
\hline
\end{tabular}

73. For the years 1956 through 1960, or since establishmont if your firm is less than 5 yoars old, about how many of your customol's havo complained of or roturned dofective morchandiso?

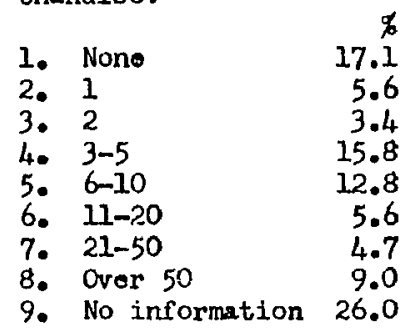

74. What was the porcentage incroisn or decroase in divjclents paid by your firm for tho yoars 1956 1960 over the previous 5 yours, 1951-1955?

0 . Firm is $1088 \quad 44.0$ than 10 yours old or thore is no information avilable

1. Over $40 \%$ docronso

\section{6}

2. 21-40\% decrosse 3.0

3. $11-20 \%$ docrease ..7

4. 1-10\% docroaso 3.0

5. No incroasso or decreaso

29.1

6. $1-10 \%$ increase 5.1

7. 11-20\% increaso 3.8

8. $21-40 \%$ increaso 3.0

9. Over $40 \%$ ini- 2.6 crv230

75. What was the percentage increnso or decroaso of applicants for the yoars 1956-1960 over the previous 5 yours, 19511955 ?

0. Firm is loss 45.3 than 10 years old or there is no information ivailablo

1. Over $40 \%$ decreaso 1.7

2. 21-40\% decroase .4

3. 11-206 decrease 1.3

4. 1-10\% decrease 4.3

5. No increaso or decreaso

24.8

6. 1-10\% incroaso 7.7

7. 11-20\% increase 5.1

8. 2l-405 increaso 2.6

9. Over $40 \%$ increase

6.8

76. What is tho percentago increase or decreaso in your firms sales volumo for the years 1956-1960 ovor the previous 5 years 1951-1955?
0. Firm is loss

$\%$

- than 10 yoers

old or there is no information availablo

1. Over 40\% docreaso

2. 21-40\% decroase 4.3

3. 11-20\% decreaso 2.6

4. 1-10\% decreaso 4.7

5. No incraaso or decrezso

6. 1-10\% increaso 13.2

7. $11-20 \%$ ins 14.1 creaso

8. 2l-40\% in- 10.3 creaso

9. Ovor $40 \%$ in- 17.5 crequo

77. For the years of 1956 through 1960, or since establishmont if your firm is less than 5 years old, approximately what has your profit beon in this period, oxprossed as a percentago of your average not worth in this poriod?

1. $0-5 \%$ of net 28.2 worth

2. 6-10\%

3. $11+20 \%$

4. $21-356$

5. $36-65 \%$

6. Over 65\%

7. No information 24.7

78. What was the porcentage increaso or decroase in the number of your employcos for the years 19561960 over the previous 5 yoars 1951-1955?

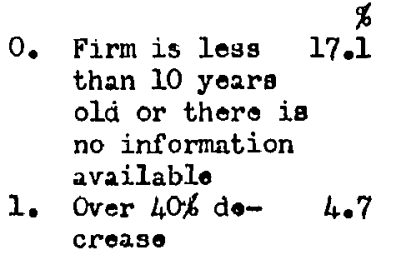

(\#78 continued on next page) 
78. (Continued)

2. 2l-40\% decrease 5.1

3. 11-20\% docreaso 3.4

4. 1-10\% docreaso 15.0

5. No increase or decreaso

15.0

6. 1-10\% increase 15.0

7. 11-20\% incroaso

B. 2l-40\% incroase

9. Ovor $40 \%$ increase 9.4 5.6

79. What was the percentago incroaso or decrease in your firm's profits for the yoars 1956-1960 over the provio'ds 5 years 1951-1955?

0. Firm is less than 10 years old or thero is no Information availablo 27.8

1. Ovor 40\% decrev.se

2. 2l-40\% decrease

3. $\mathrm{u}-20 \%$ docrenso

4.. 1-10\% docroase 12.8

5. No incroaso or dacreaso

12.1 :

6. 1-10\% increase 17.5

7. 11-20\% incrovso

8. 21-40\% increase Over 406 increaso

80. What was the porcontage increase or decroase in your firm's investinent in expansion for the years 1956-1960 over tho provious. 5 years 1951-. 1955 ?

0. Firm is less than 10 yoars old: or thera is no information 2vailable
1. Over $40 \%$ decroaso

2. 21-40\% docrezse 2.9

3. $11-20 \%$ decreaso 1.7

4. $1-106$ decrease 1.3

5. No increase or decroase

13.2

6. 1-10\% increaso 16.2

7. 1I-20\% increaso

10.3

B. 2l-40\% incrossa 9.4

9. Over $40 \%$ increaso

1.3 .4

81. In tho lust 10 yoars, or since establishment of your firm if less than 10 years old, to what extent has mochanization or uutomation roduced your potential workforce relative to if those chenges wero not initiated? (Do not include replacemont of old machinery.)

1. Not at all

2. $0-5 \%$ 13.2

3.. 6-106 7.7

4.. $11-15 \%$

5.. $16-25 \%$

6. . Uvor 25\% 6.0

7. No information 31.5

82. About what porcentage of your management personnel hold one or moro offices in. various civicrand charitible organtsations?

1. None 17.1

2. . $1-5 \%$ 26.1

3. $6-10 \% \quad 8.5$

4. $1 I-25 \%$

5. $26-40 \%$

6. $4,1-60 \%$

7. $61-30 \%$

8. . 81-100\% 13.2

9. . No information 1.1 .1
Survey Controls

83. Do you wish to receive a a complimentury copy of a synopsis of the survoy findings?

$\begin{array}{lr}\text { 1. no } & 6.4 \\ \text { 2. yos } & 91.5 \\ \text { N. A. } & 2.2\end{array}$

34. About how many man-hourg did it tako to comploto this questionnaire?

$\begin{array}{llr}\text { 1. } 0-1 & \% \\ 2 . & 1-2 & 47.9 \\ \text { 3. } 2-3 & 36.8 \\ \text { 4. 3-4 } & 6.8 \\ \text { 5. Over 4 } & 2.6 \\ \text { N. A. } & 1.7 \\ & & 2.1\end{array}$

N. A. 


\section{APPENDIX B}

Organization Questionnaire

(Front side) 


\section{Organization Questionnaire}

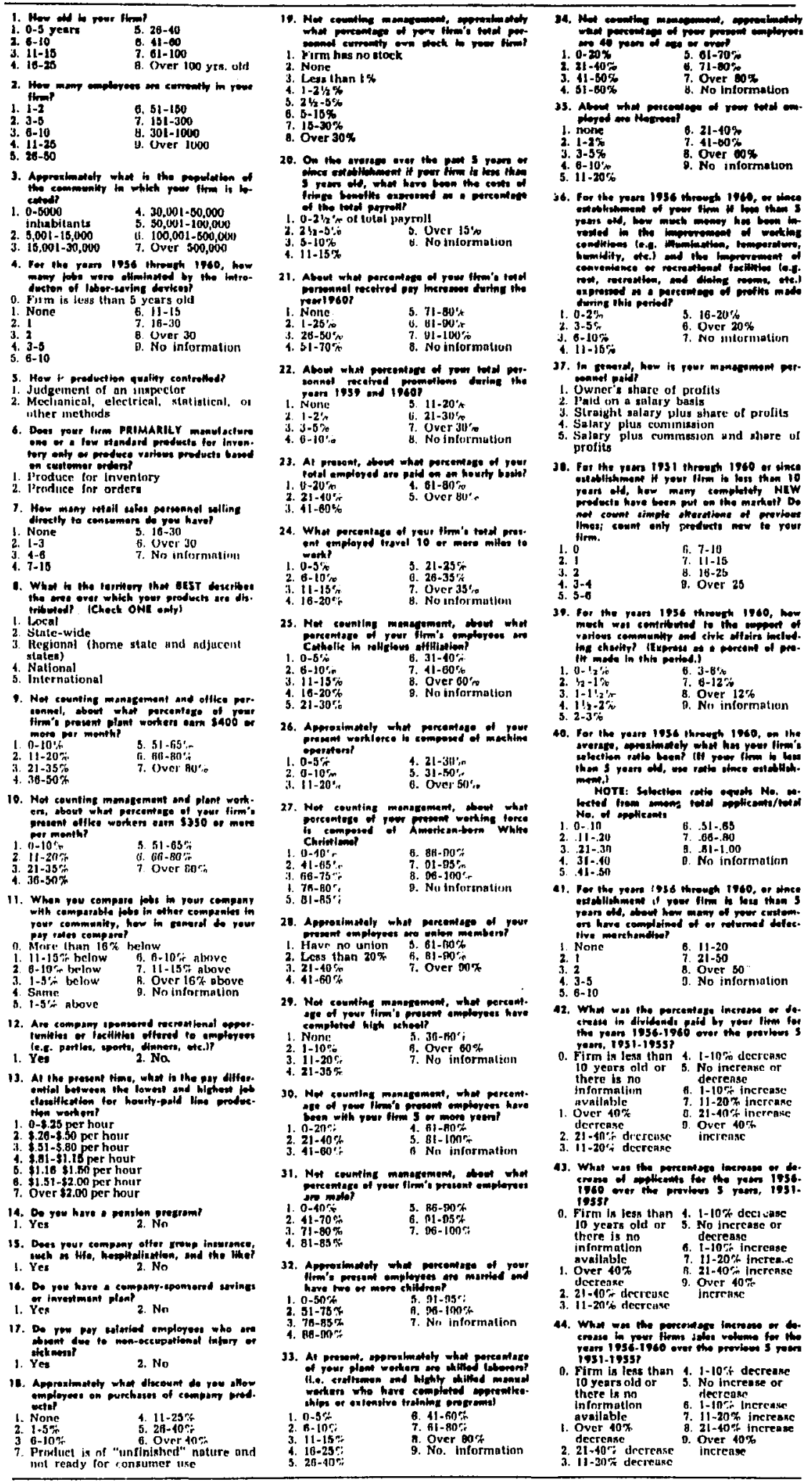

(Continued on Revrrse Side) 
APPENDIX B Cont'd.

Organization Questionnalre

(Back Bide)

68 


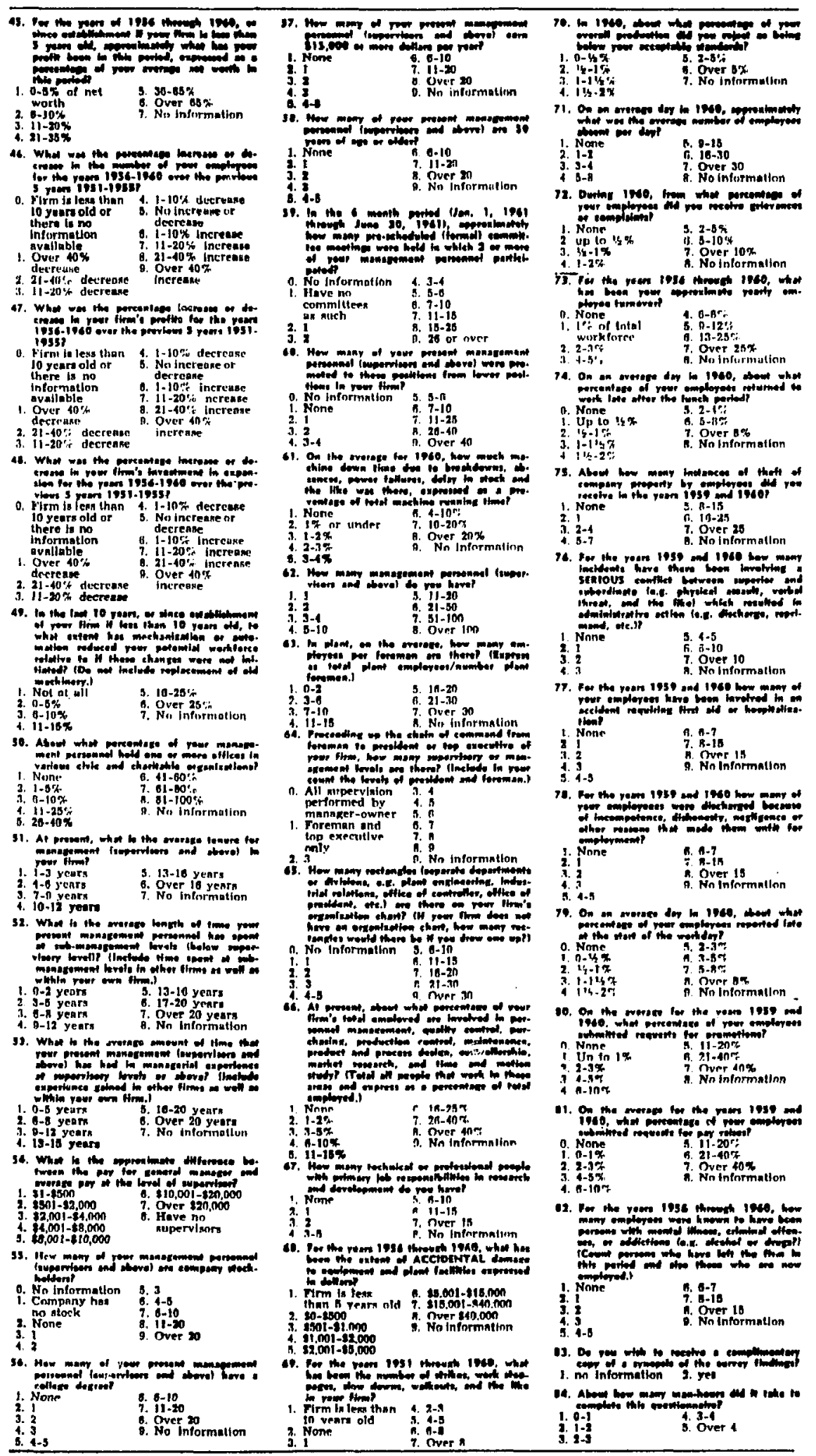


APPENDIX $C$

IBM Mark Sense Cards

Card I (front side)

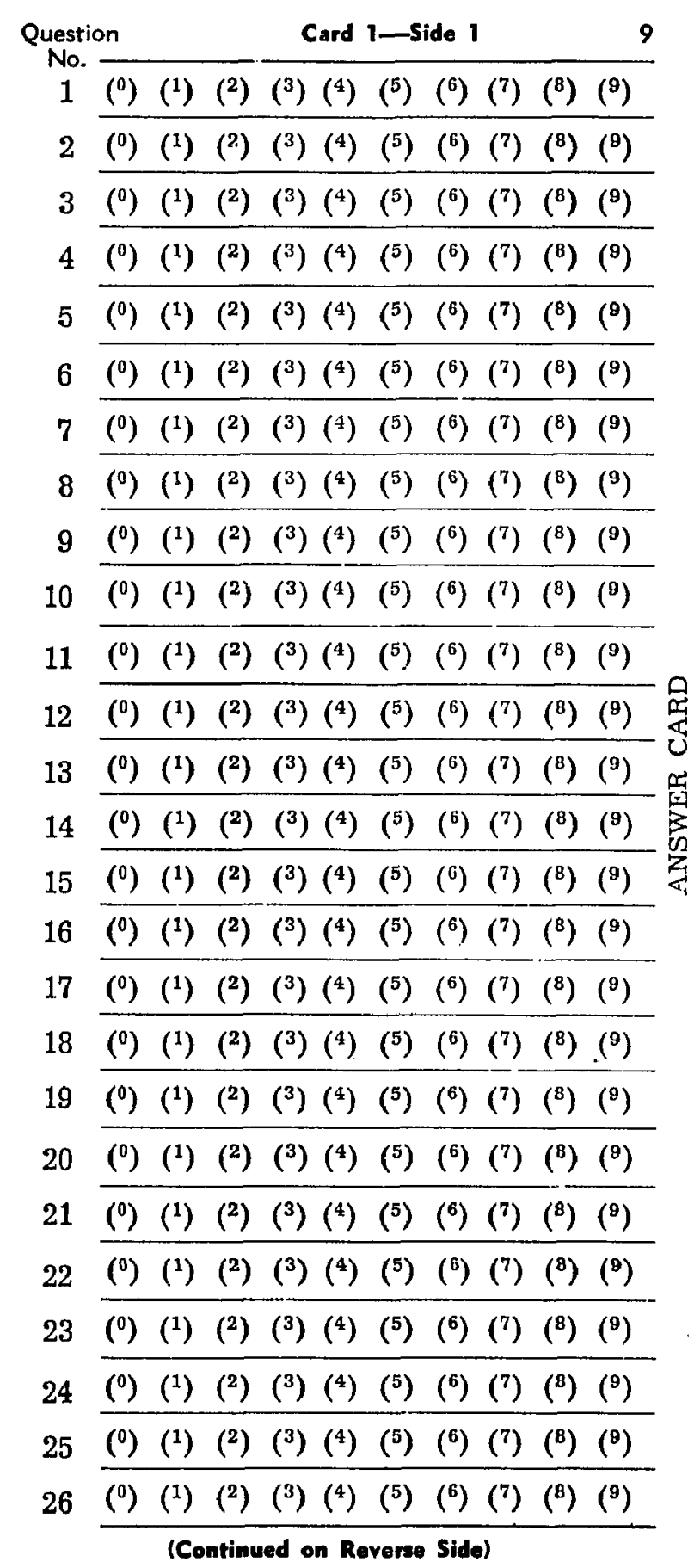




\section{APPEHDIX C Cont'd.}

\section{IBM Mark Sense Cards}

\section{Card I (back stde)}

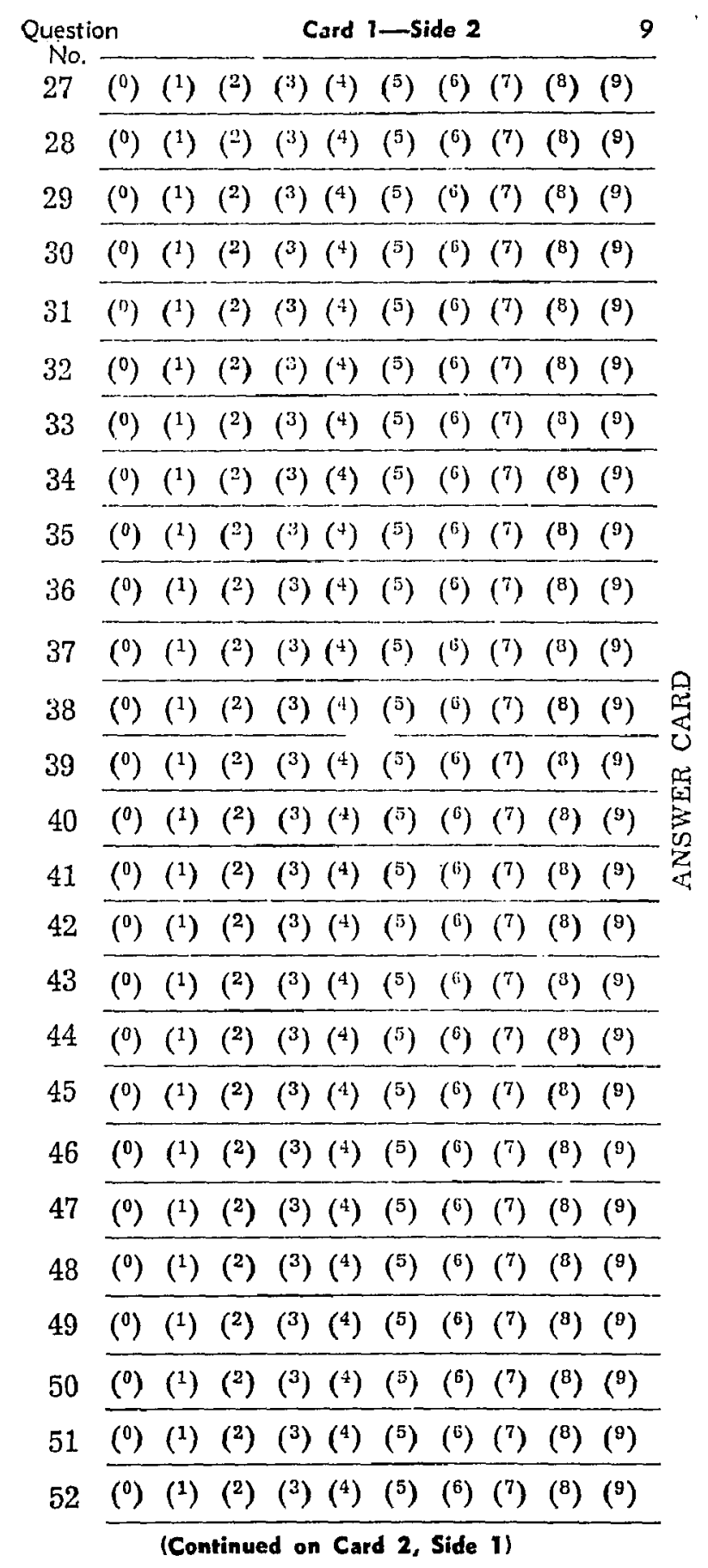




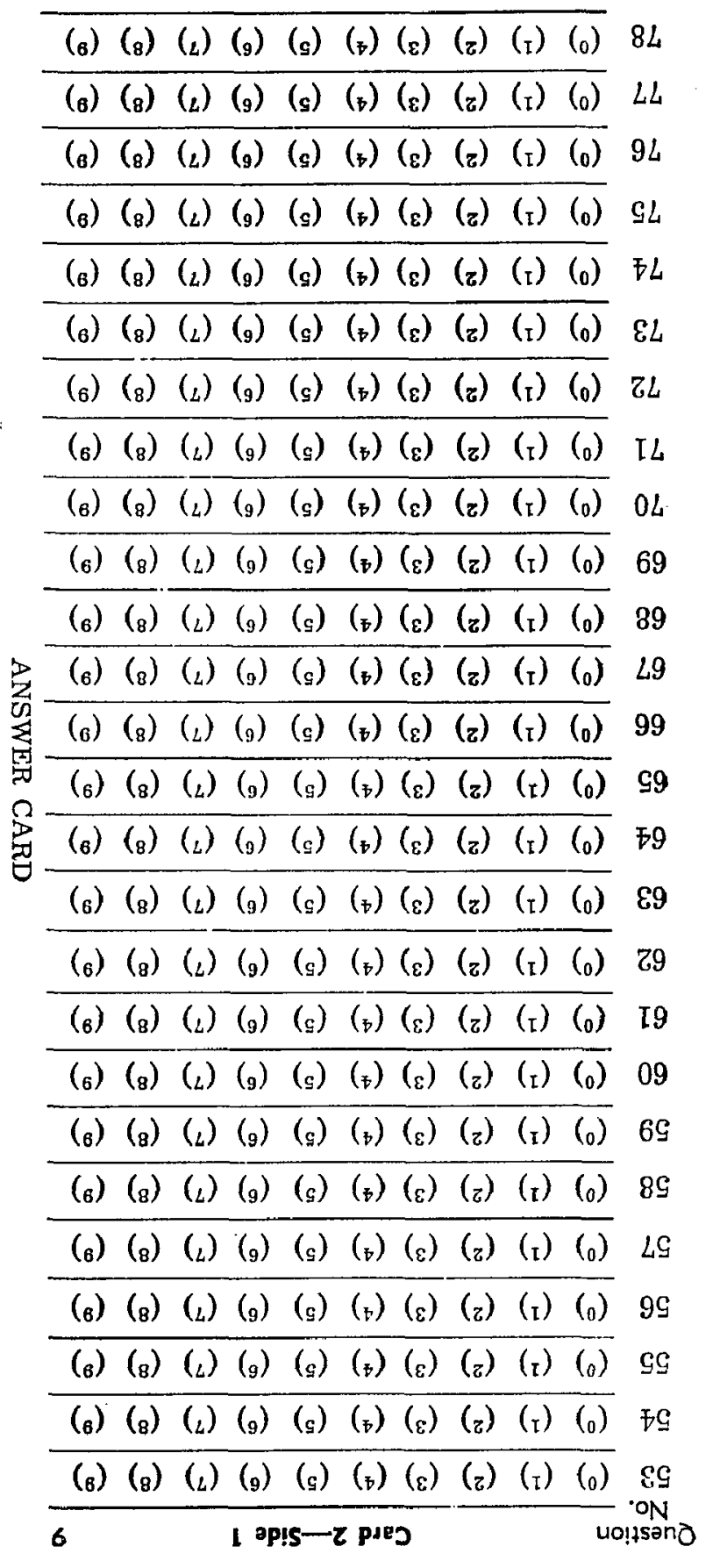

(อртв 7U0xy) 2 pres

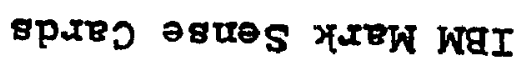

•p.quOS $\rho$ XIGNGddV 


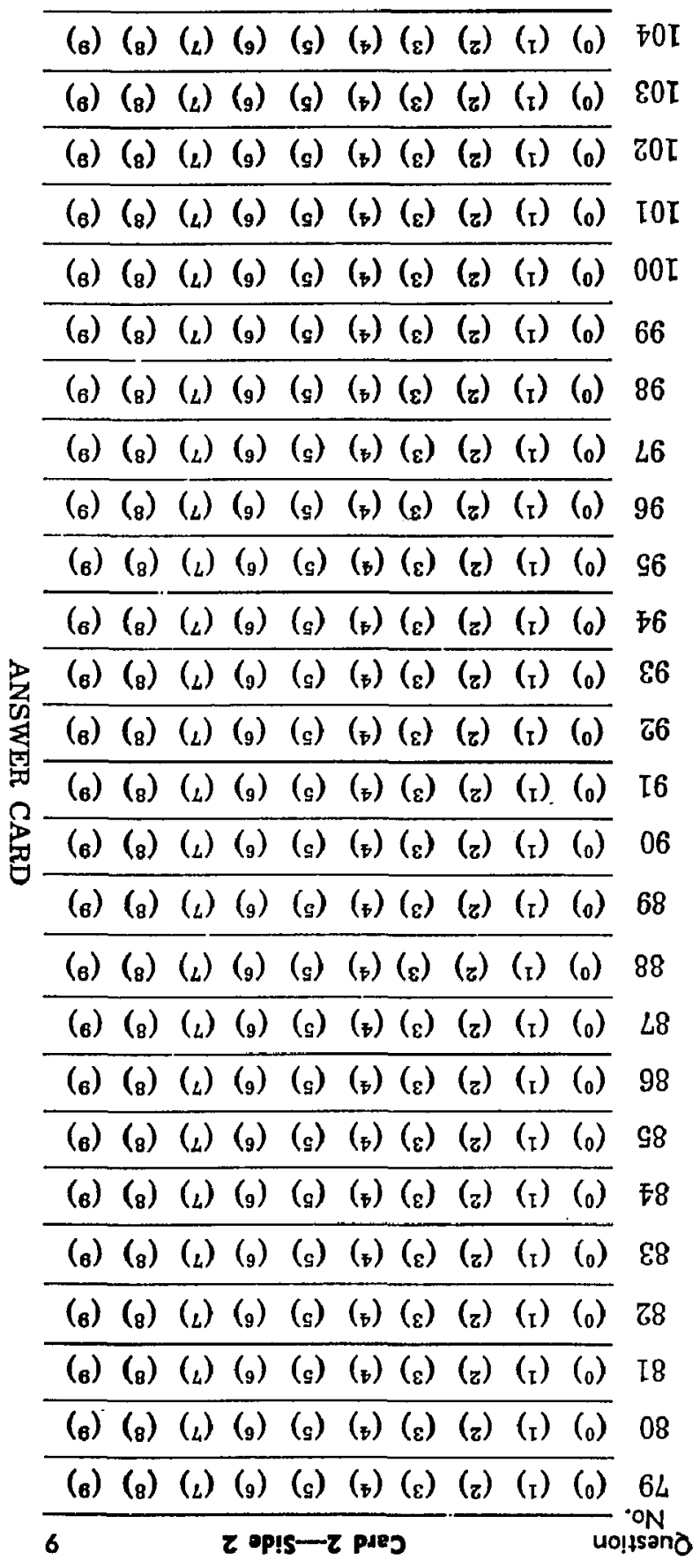

(วpfs yoeq) 2 prej

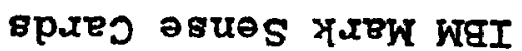

- $p$, quOD 5 XIवNGddH 
APPENDIX D

Coverlng Letter for Initial Survey 


\author{
OFFICE OF ORGANIZATION RESEARCH \\ Psychology Department \\ Peabody Hall \\ Louisiana State Unfversity \\ Baton Rouge 3, Louisiana
}

January 22, 1962

Dear Sir:

We are requesting your cooperation in conducting a nationwide survey to determine various characteristics of industrial firms. The enclosed questionnaire is comprised of questions concerning various personnel policies, management and worker characteristics as well as general characteristics (e. g., age of firm, number of employees) of industrial firms.

Enclosed with the questionnaire are two answer cards. For each question on the questionnalre, select the one option athat best describes your firm and fill in the appropriate box on the answer cards with a soft No. 1 or No. 2 lead pencil like this (O).The transferring of your answers to the answer cards will both facilitate data analysis and allow you to keep the questionnaire for reference purposes. If you are a branch of a larger firm, then please report data for your branch only. Please anwer all questions and return the two answer cards to us in the return envelope.

We will be glad to send you, within a few months, a synopsis of the findings from the first survey which is to be comprised of the returns from 3,000 manufacturing firms throughout the continental United States. If you desire a synopsis, please indicate so by checking the yes option of the appropriate item (next to last item on the questionnaire).

Your cooperation in returning the questionnaire will be greatly appreciated and you can rest assured that the data pertaining to your particular firm will be held in strict confidence. The synopsis is . to be composed of summary cabulations which will in no way identify individual firms.

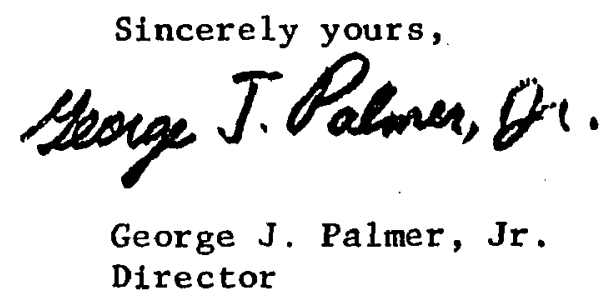

Enclosures: 
APPENDIX E

Covering Ietter for Reliability Sample 


\section{OFPICE OP ORGANIZATION RESEATCH \\ Psycholopy Dopartiont \\ Peabody Hall \\ Louisiana State University \\ Baton Rouge 3, Louisiana}

March 15, 1962

Dear SIr:

We have recelved your reply to our survey and appreclate very much your cooperation in this matter.

Before we tabulate our returns, we are checking to make sure that our racords are correct and complete for all companies which have replied to our survey. In order to facilitate this checking, we would like to ask for your cooperation by your answerting again the enclosed questionnaire from your own records. Please circle the correct answer on the enclosed printed questionnaire and kindly return it to us in the return envelopo.

As we have indicated before, all of this information will be held in the strictest confidence. The summary repori, which we will send to all cooperating firms, will contain only summary tabulations which will in no way identify individual firms.

This cross check on our information will help us to establish the accuracy of information to be included in our report to you. It will be appreciated if you will please return this questionnaire to us as soon as possible so as to assure the timeliness of the report.

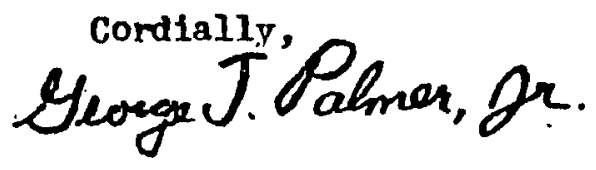

George J. Palmer, Jr., Ph.D. Industrial Psychologist Director

GJP:ds

Enclooures 


\section{APPENDIX $F$}

Covering Letter for Follow-up Sample 


\section{OFFICE OF ORCANIZATICN RBSEARCH Peychologs Departisont \\ Peabods Hall \\ Ioulolana State Univorsit. \\ Baton Rouge 3, Loulstana}

March 15, 1962

Dear Sir:

About six weeks ago you recelred a request to cooperate in a survey of American manufacturing firms. We hope that you will be able to cooperate with us and answer the questionnaire wich was sent to you. It is our desire to have a large and representative sample of American companies in this ourvey 80 as to make the information more generally useful.

We are enclosing for your convenience an additional copy of the questionnalre which you may answer simply by circling the correct answer and returning this in the enclosed envelope.

As we have indicated before, all of this information will be held in the strictest confidence. The summary report, which we wlll send to all cooverating firms, will contain only summary tabulations which will in no way identify indiridual firms.

It will be approciated if you will please return this questionnaire to us as soon as possible so as to assure the timeliness of the report. If you have already retumed our questionnaire, please disregard this reminder.

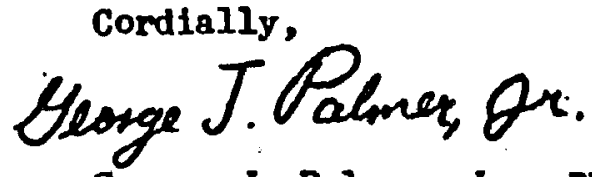

Georre J. Palmer, Jr., Ph.D. Industrial Psychologist Diroctor

GJP:ds

Enclosures 
VITA

George Henry Dunteman was born September 10, 1935, in Ilttle Falls, New York. In June, 1957, he received the degree of Bachelor of Arts in sociology from Saint Lawrence Unirersity, Canton, New York. In June, 1959, he was awarded the degree of Master of Sclence in applied psychology from Iowa State University, Ames, Iowa. He entered Louisiana State University in September, 1959, and became a candidate for the degree of Doctor of Philosophy. 
EXAMINATION AND THESIS REPORT

Candidate:

Major Field:

Title of Thesis:
George Henry Dunteman

Psycho logy

ORGANIZATIONAL CONDITIONS AND BEHAVIOR IN 234 INDUSTRIAL MANUF ACT UR ING ORGANIZATIONS

Approved:

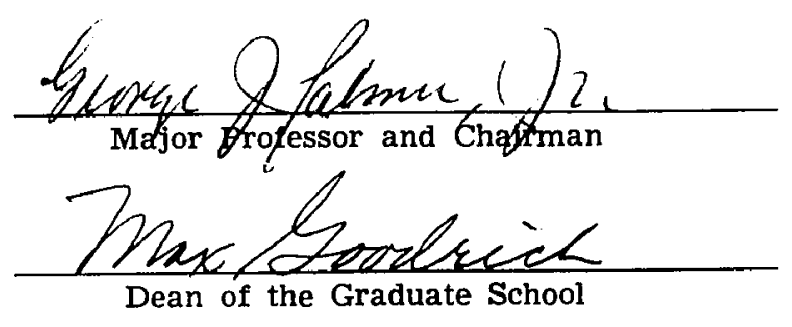

EXAMINING COMMITTEE:
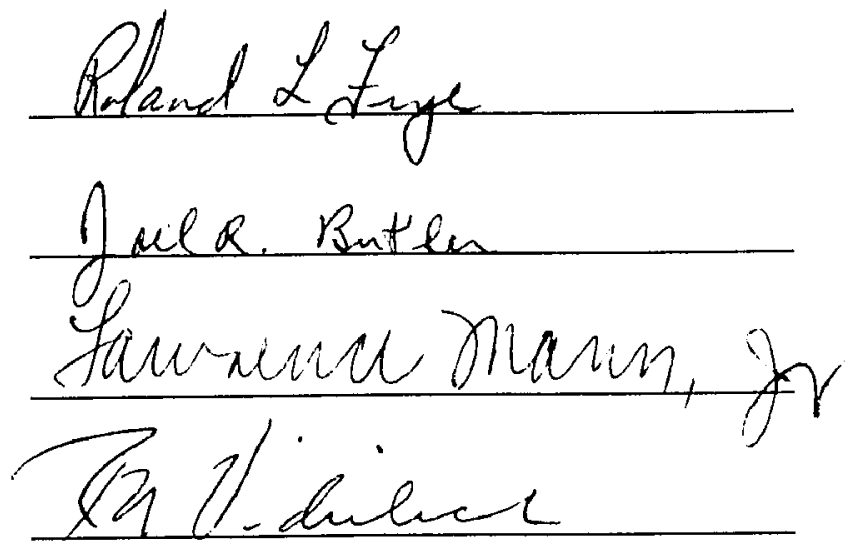

Date of Examination:

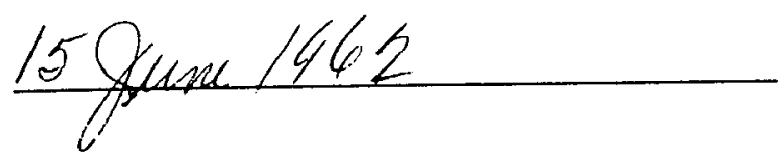

